This item was submitted to Loughborough's Research Repository by the author.

Items in Figshare are protected by copyright, with all rights reserved, unless otherwise indicated.

\title{
A bibliometric analysis of research in design for additive manufacturing
}

PLEASE CITE THE PUBLISHED VERSION

https://doi.org/10.1108/RPJ-11-2020-0291

PUBLISHER

Emerald

VERSION

AM (Accepted Manuscript)

PUBLISHER STATEMENT

This paper was accepted for publication in the journal Rapid Prototyping Journal and the definitive published version is available at https://doi.org/10.1108/RPJ-11-2020-0291

\section{LICENCE}

CC BY-NC 4.0

\section{REPOSITORY RECORD}

Obi, Martins, Patrick Pradel, Matt Sinclair, and Richard Bibb. 2022. "A Bibliometric Analysis of Research in Design for Additive Manufacturing”. Loughborough University. https://hdl.handle.net/2134/17113820.v1. 


\section{A Bibliometric analysis of research in Design for Additive Manufacturing}

\section{Abstract}

Purpose: Design for Additive Manufacturing (DfAM) provides an opportunity to harness the capabilities of Additive Manufacturing. Research shows that knowledge has been developed which cuts across different aspects in the field. Hence, as an emerging research area, it is imperative to understand how the knowledge in this field is developing and its significance to both academia and industry.

Methodology: In this paper, we use a bibliometric approach to analyse publications from January 2010 to December 2020 to explore the subject areas, publication outlets, most active authors, geographical distribution of scholarly outputs, collaboration and co-citations at both institutional and geographical levels, and outcomes from keywords analysis.

Findings: Our findings reveal that most knowledge has been developed in DfAM methods, rules, and guidelines. This may suggest that designers are trying to learn new ways of harnessing the freedom offered by AM. Furthermore, more knowledge is needed to understand how to tackle the inherent limitations of AM processes. Moreover, DfAM knowledge has thus far been developed mostly by authors in a small number of institutional and geographical clusters; potentially limiting diverse perspectives and synergies from international collaboration which are essential for global knowledge development, the improvement of the quality of DfAM research, and its wider dissemination.

Originality: A concise structure of DfAM knowledge areas upon which the Bibliometric analysis was conducted is developed. Furthermore, areas where research is concentrated and those that require further knowledge development are revealed.

\section{Keywords}

Design for Additive Manufacturing (DfAM), DfAM Knowledge, Bibliometrics, Scopus.

\section{Introduction}

Design for Additive Manufacturing (DfAM) consists of methods and tools that support the design of products that fulfil functional and life-cycle objectives considering the particular potentials and limitations of Additive Manufacturing (AM) (Ponche et al. 2014) enabling the achievement of desired requirements and the maximisation of product performance (Chu, Graf and Rosen, 2008). DfAM provides the opportunity to rethink, refine and redesign existing components by employing the capabilities of $A M$ to improve value (Rosen, 2014). DfAM comprises methods, principles, heuristics, systems and tools that enable the design of AM conformal designs (Kumke, Watschke and Vietor, 2017). Research in DfAM has evolved over the last decade and a 
consensus has been reached that DfAM can leverage the potentials of AM to expand the possibilities of design (Pradel et al., 2018). However, to fully exploit AM, designers need to "un-learn" the constraints of traditional manufacturing processes that are deeply engrained in current design practices (Blösch-Paidosh and Shea, 2019). Over the past decade, there has been an increase in the published academic literature addressing the need for the uptake of $\mathrm{AM}$ as a mainstream manufacturing technology for industrial applications. Whilst designers need to learn how to take advantage of the capabilities of AM, they are hampered by currently available knowledge that is fragmented, incomplete and incoherent (Pradel et al., 2018).

This paper aims to shed more light on the state of DfAM research and to provide focus and direction for future research. To achieve this, we conducted an extensive bibliometric analysis of DfAM literature. This analysis will assist the organisation of the body of knowledge that is currently fragmented and without well-defined boundaries. A coherent organisation of the literature could unveil promising research directions that can inspire practitioners and provide guidance to future studies.

Section 2 provides definitions and descriptions of the DfAM classifications as a approach to organise the literature. Section 3 describes the overall bibliometric approach and literature search protocol. In section 4, the results of the bibliometric analyses are discussed, and section 5 discusses the outcome of the keyword analysis and summarises the findings.

\section{DfAM Classification}

Earlier studies have attempted to classify DfAM knowledge (Yang \& Zhao, 2015; Blösch-Paidosh \& Shea, 2018; Laverne et al., 2017). Although incomprehensive, these studies provided a foundation for the knowledge classification in DfAM. With the evolution of DfAM knowledge, broader classifications have emerged. For instance, the work by Kumke, Watschke and Vietor, (2016) which used a basic design process model as a framework for organising DfAM knowledge was expanded by Pradel et al., (2018) to include the knowledge from post-processing and manufacturability issues. Furthermore, a more elaborate classification proposed by Kumke, et al. (2018) defined DfAM knowledge in the broad sense and in the strict sense. DfAM in the broad sense covered methodologies, design potentials and rules, whilst DfAM in the strict sense addressed process selection, production strategy, manufacturing analysis, part 
selection, and application. Despite the attempt at a holistic classification, the knowledge that emanates from manufacturing technology was not captured. The authors argued that activities concerning manufacturing processes are the responsibility of the manufacturing specialist and not the designers.

The aim of this study is to shed more light on the state of DfAM research and to provide focus and direction for future research. To achieve this, we conducted an extensive bibliometric analysis of DfAM literature. To organise the literature and provide a structure for the bibliometris analysis, we expand the classification by Kumke, et al. (2018) to develop a holistic DfAM classification comprising of four knowledge streams (see figure i). We adopt DfAM in the "broad sense" to be "DfAM potentials" and classify the DfAM Limitations as the constraints inherent in the AM processes. Furthermore, we refer to literature that specifically addresses DfAM design methods, tools, rules and guidelines as "DfAM Specifics" and contrary to Kumke, et al. (2018), we argue that the knowledge of the manufacturing process is critical in the design phase. This aligns with the work by Christopher, Logan and Alfred, (2015) where the authors concluded that topics such as AM processes and process/material relationships are critical to leveraging the potentials of AM. Therefore, we refer to such knowledge as knowledge from "AM processes". The proposed classification is important because it offers a more holistic approach to DfAM knowledge classification. Moreover, designers require complete, structured, and easy to understand knowledge to exploit the potentials offered by AM (Pradel et al., 2018b). The description of the proposed classification of DfAM knowledge as an approach to conduct the bibliometric analysis is presented in the following sessions. 


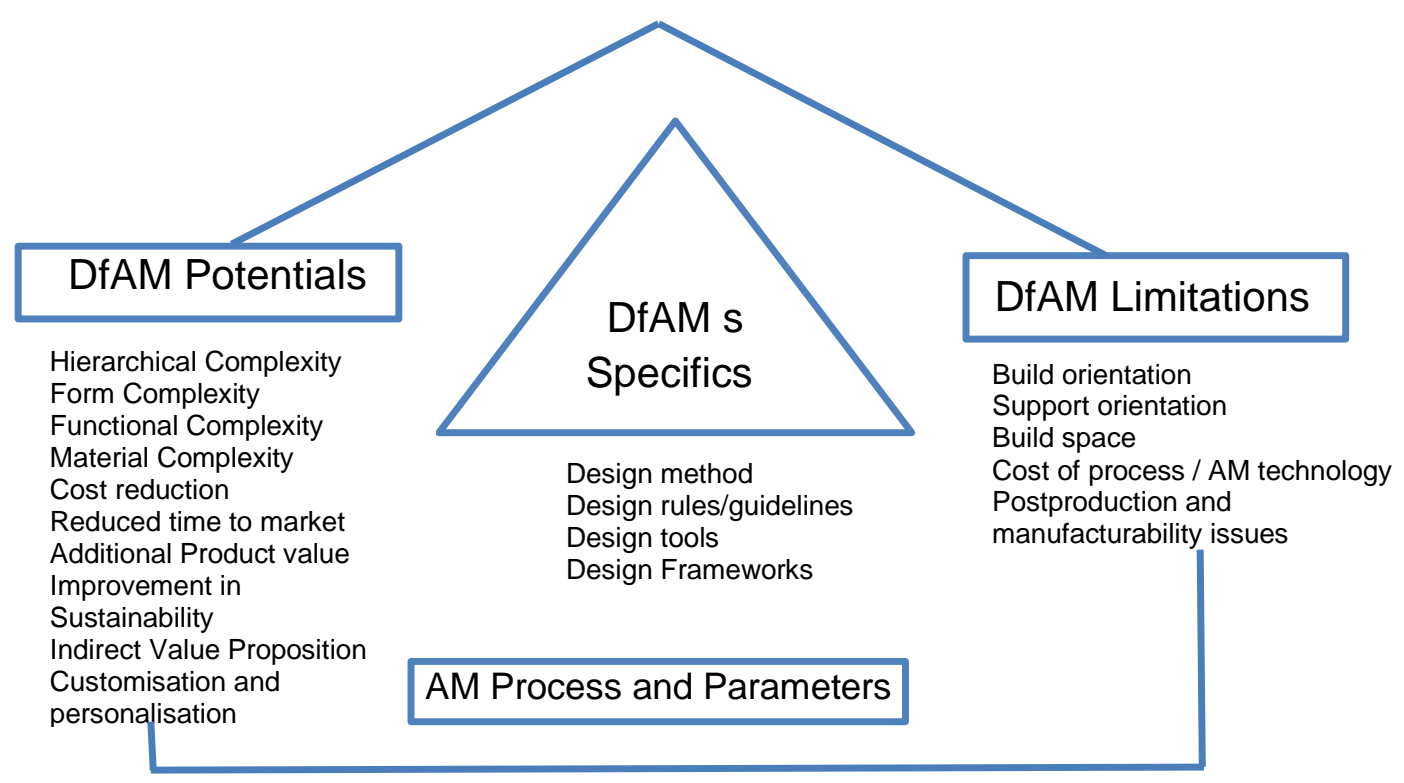

Figure i- DfAM Classification

\subsection{DfAM Potentials (Opportunistic DfAM)}

The rapid growth of $A M$ has provided designers with access to these new manufacturing technologies, necessitating the development of expertise and processes for optimised AM specific design. DfAM potentials are the unique capabilities that are offered by AM compared to conventional manufacturing processes (Gibson, Rosen and Stucker, 2014). In this study, we adopt the classification by Kumke et al., (2018) and propose eleven subclasses of DfAM potentials, using the relationship between levers and value propositions (Baldinger et al., 2013) as shown in figure ii. Levers provide several types of design freedom such as the capability to manufacture intricate shapes, undercuts, non-uniform wall thicknesses, etc. The benefits reaped by the customer of the product are referred to as value propositions. In the current study, we support the argument by Kumke et al., (2018) that the levers are not ends in themselves but rather, a means to an end and the enablers for value propositions in DfAM. Over the past decade, AM potentials have evolved and have been brought to the fore by various researchers For instance, an early work by (Rosen, 2007) identified the unique capabilities of $A M$ to include shape complexities - the possibility to build any shape, customised geometries, and optimised shape (Gibson, Rosen and Stucker, 2014); material complexities, manufacturing components with digital materials and complex material compositions, ability to use different materials on different layers of a structure (Hegab, 2016; Tammas-Williams and Todd, 2017) and hierarchical complexities - the ability to design and fabricate parts from 
microstructure, through geometric mesostructured to part-scale macrostructure (Shabat and Fischer, 2015). Furthermore, Chu, Graf and Rosen, (2008) identified shape complexity and material complexity as the two major capabilities of $A M$ that have the potential to improve the adoption of AM for industrial applications. Kumke et al., (2018) built on the work by (Rosen, 2007) to propose functional complexity as a capability of AM. Functional complexities in $\mathrm{AM}$ are addressed in part consolidation, compliant mechanisms, functional expansion, etc (Tang, Hascoet and Zhao, 2014; Jansen, Doubrovski and Verlinden, 2014). Despite the high cost of AM machines, AM processes have the potential to reduce the overall manufacturing cost of AM parts. By developing cost estimation models, research has studied how AM technologies can be successfully applied in small to medium batch production of end-use metal parts (Atzeni and Salmi, 2012; Baldinger et al., 2016). AM processes have shown the potential to reduce time to market and strengthening the supply chain of organisations. Using a simulation approach, Chiu, MC and YH, Lin, (2016) integrated Design for Supply Chain with DfAM to ascertain the impact of supply chain configuration for a personalised product optimised under various demand uncertainties. The push for the adoption of AM as a manufacturing technology for end-use products is evident in the additional product values that it offers. Such values include increased product performance, multifunctionality, reduced cost etc. (Atzeni and Salmi, 2012; Lettori et al., 2020). Furthermore, AM presents the possibility of improved product sustainability. Gebisa and Lemu, (2017) analysed the possible paradigm shift from Design for Manufacturing (DfM) to DfAM and its impact on realising optimum design and the requirements for product sustainability. Similarly, Taddese, Durieux and Duc, (2020) proposed sustainability performance indicators for AM based on product life cycle studies. AM presents huge potentials in customised and personalised products especially in medical prosthetics (Lim et al., 2017), tissue engineering (Spallek and Krause, 2016a), and protective products (Ellena et al., 2018). Although AM is continuously evolving, it is evident that research is ongoing to uncover the various approaches to reap the benefits of the technology at an optimised cost and reduced time.

\subsection{DfAM Limitations (Restrictive DfAM)}

The current study defines DfAM limitations as the restrictions associated with current AM processes. Just as with the potentials, it is necessary to consider these restrictions 
in the design process (Leutenecker-Twelsiek, Klahn and Meboldt, 2016). AM is associated with some problems that reduce process efficiency regarding time, cost, and material usage, and may give rise to failure in the manufacturing process (Ponche et al., 2014; Gao et al., 2015). These problems and restrictions are classified as DfAM limitations (Ranjan, Samant and Anand, 2015).

Due to planar layer-additive manufacture, the rotation of the part in the build space around the axes of the machine' coordinate system, that is thepart orientation with respect to the build plane, (Leutenecker-Twelsiek, Klahn and Meboldt, 2016) has a significant impact on the mechanical properties of the part and affects the final part quality and geometry (Zwier and Wits, 2016) which presents implications for design. Parts produced by AM have dimensional limitations due to the machines' build space capabilities (Oh, Zhou and Behdad, 2018a; Ramírez et al., 2019) consequently, parts may have to be designed as assemblies; known as part decomposition (Oh, Zhou and Behdad, 2018b). Post-production complexities are experienced due to errors from AM's digital and physical process chains that result in inconsistencies in the geometries of the final products (Polini et al., 2017), as a result, issues like tolerances should be addressed to control the geometrical deviations of the final product (Zhu et al., 2018). More so, the use of support structures leads to additional material usage and increases build time and post-processing effort (Zeng, 2015) because they are non-functional frames normally fabricated together with the functional parts and removed after the build process (Järvinen et al., 2014). In fact, they are sacrificial features of AM that should be taken into consideration at the design phase (Ameen et al., 2018). Manufacturability constraints such as enclosed voids are addressed by (Liu et al., 2015).

\subsection{DfAM Specifics}

The rapid evolution of $A M$ technologies for the manufacture of end-use products requires the development of new frameworks, methods, tools, rules, and guidelines. DfAM specifics refer to the frameworks, methods, tools, rules, and guidelines that assist designers to exploit the capabilities of AM. In the last decade, research in these areas has become more prominent. For instance, Qi et al., (2018) encapsulated and modelled knowledge into a categorical framework, which enables existing knowledge and state-of-the-art design cases to become computer-readable and integrated into 
computer-assisted software (CAx) platforms. Similarly, Pradel et al., (2018b) utilised a consistent and systematic framework based on a generic design process to map existing DfAM knowledge. Furthermore, Ko, Moon and Otto (2014) addressed customisation issues around DfAM frameworks by representing design knowledge for customisation and systematically reflecting customised design factors to DfAM frameworks. Kumke, Watschke and Vietor (2017) integrated existing methods and tools from DfAM and general design methodologies into a modular framework to support design engineers in all product development stages. Such modular frameworks are scalable, flexible, and accessible to design engineers and can be deployed at all product development stages. Design methodologies for DfAM have been proposed in various studies. Laverne et al., (2015) explored existing DfAM methods and presented an assembly based DfAM method using AM knowledge in the conceptual design phase. Such DfAM methods have been demonstrated in the design of microwave components (François et al., 2019), mechanical systems (Orquéra, Campocasso and Millet, 2017) and the optimisation of pipe networks in compact systems (Cao et al., 2018). Some studies have fused other design methods with DfAM. For instance, Clausen, Aage and Sigmund, (2015) and Ranjan, Samant and Anand, (2016) optimised components for DfAM using topology optimisation. Kretzschmar and Chekurov (2018) applied the Theory of Inventive Problem Solving (TRIZ) in conjunction with DfAM to create novel shapes, geometries, and enhanced functionalities. Similarly, the axiomatic design method has been applied in DfAM by Salonitis (2016). Research in DfAM has also provided rules and guidelines to enable designers to capitalise on the expanded design space due to the implementation of AM in product development. Design rules for AM processes were extracted and categorised by Mani, Witherell and Jee (2017). Similarly, valuable guidelines for part decomposition were generated by Liu (2016). More recently, Greer et al., (2019) reported with a case study approach on how design rules such as the overhang constraint, large weld, bead thickness, and support structures interact. 


\subsection{AM Process and Parameters}

AM process and parameters play a critical role in determining the outcome of the printed part. Furthermore, the choice of process parameters can impact the properties of the final product and support its load bearing capacity (Guariento et al., 2020). Ameen et al., (2018) studied the effect of process parameters on the performance of the support structures during AM. Their findings reveal that the support structures' parameters can increase the accuracy of the fabricated objects and impact the cost of the applied support by reducing the support volume (Tavcar and Nordin, 2021). Various studies have derived design knowledge from AM processes. One of the earliest studies by Vayre, Vignat and Villeneuve (2013) investigated the manufacturing constraints in Electron Beam Melting (EBM) and issued recommendations to designers. Ponche et al., (2014) examined the printing of thin wall metal parts using Powder Bed Fusion (PBF). Efforts have been made by researchers to study manufacturing issues arising from the use of some AM technologies. Ameen et al., (2018) investigated the manufacturability of round holes with and without supports in EBM using Ti6A14V powder. Likewise, Chekurov and Lantela (2017) addressed the dimensional inaccuracies associated with Selective Laser Melting (SLM) using the redesign of an existing manifold. In Material Extrusion (MEX) Tronvoll, Elverum and Welo (2018) characterised dimensional inaccuracies using image analysis. Also, Wulle et al., (2017) attempted to provide design opportunities and enhance workpiece properties while considering the constraints associated with multi-axis FDM. Materialprocess interaction for vat polymerisation (VPP) processes was investigated by Aznarte Garcia, Qureshi and Ayranci, (2018). The knowledge of process parameters is key to the decisions made by the designer at every design stage. Again, some researchers have sought to understand the impact of process parameters in DfAM. A more recent study by Hallmann, Schleich and Wartzack, (2019) developed a method that allows the study of both design and process parameters simultaneously while considering the machine in use. Furthermore, Castelão et al., (2019) evaluated the surface finish and dimensional deviations of parts printed with FDM when considering multiple parameters and using design of experiments coupled with the response surface methodology. 


\section{Method}

A standard bibliometric procedure was deployed to investigate the intellectual core structure of the dispersed yet emerging research in DfAM. As shown in figure ii, the review process started by defining the study protocol. The aim was to focus on peerreviewed journal articles, conference papers, and review articles that examined DfAM, detailing how design can take advantage of AM potentials, overcome limitations, by using design specifics and AM technologies. To achieve this, Scopus (www.scopus.com), a comprehensive abstract and citation database of scientific journals, books and conference proceedings was employed, due to its integration within the academic community, unbiased and reliable analyses of its selection procedure. Scopus indexes literature from the top-ranking publishers including Elsevier, Springer, Taylor \& Francis, Sage, Emerald, IEEE, and Cambridge University Press.

The search was limited to documents published in English from January 2010 to December 2020 (when the analysis was conducted) because it was intended to examine the growth of the DfAM research area in this current decade. Books and book chapters were excluded from the search due to restricted access and the cost of acquisition.

To identify articles for analysis, database searches within titles, abstracts and keywords were conducted using "Additive Manufacturing" as the primary search phrase. The search revealed 23,311 documents most of which related to the development or validation of $A M$ technologies and processes. To fulfil our aim to analyse the design aspects of $A M$, the search was redefined and narrowed down using "Additive Manufacturing" and "Design" as the search terms. The new search produced 8,475 articles. The possibility of obtaining a substantial number of publications whose content does not address the impact of design on AM potentials, limitations, processes and specifics, led to a further redefinition of the search terms. The redefined search terms were obtained from a preliminary investigation of research articles that focused on DfAM. "Design for Additive Manufacturing", "Design for 3D printing" and "Design for Rapid Prototyping" were used as search phrases and produced 385, 27, and 19 outcomes respectively for each search phrase. To avoid repetitions in the search output, and due to its wide acceptance by both industry and the research communities, "Design for Additive Manufacturing" was adopted. Pre-processing was conducted 
which included exporting all references to Mendeley and performing a second analysis. The pre-processing activities reduced the document count to 349 , due to lack of access to some of the articles and removal of duplicates. To ensure that the conceptual classification of DfAM was clearly identified in the 349 articles, first, the titles, keywords and abstracts were analysed to identify and remove false positive outcomes. Second, where clarity was needed regarding the content of the articles, the full paper was read and analysed. 
analysis approach i.e. bibliometric

id the research reveal nove

indings?

How should future research

visualisation and content analysis.

proceed?

\begin{tabular}{|c|c|c|c|c|}
\hline $\begin{array}{l}\text { Step } 1 \\
\text { Research Objective }\end{array}$ & $\begin{array}{l}\text { Step } 2 \\
\text { Research Design }\end{array}$ & $\begin{array}{l}\text { Step } 3 \\
\text { Bibliometric Data } \\
\text { collection }\end{array}$ & $\begin{array}{l}\text { Step } 4 \\
\text { Analysis and } \\
\text { results }\end{array}$ & $\begin{array}{l}\text { Step } 5 \\
\text { Interpretation of } \\
\text { findings }\end{array}$ \\
\hline
\end{tabular}

Figure ii - Research Protocol 
These activities further reduced the number of articles to 302 as described in the PRISMA Flowchart in Figure iii.

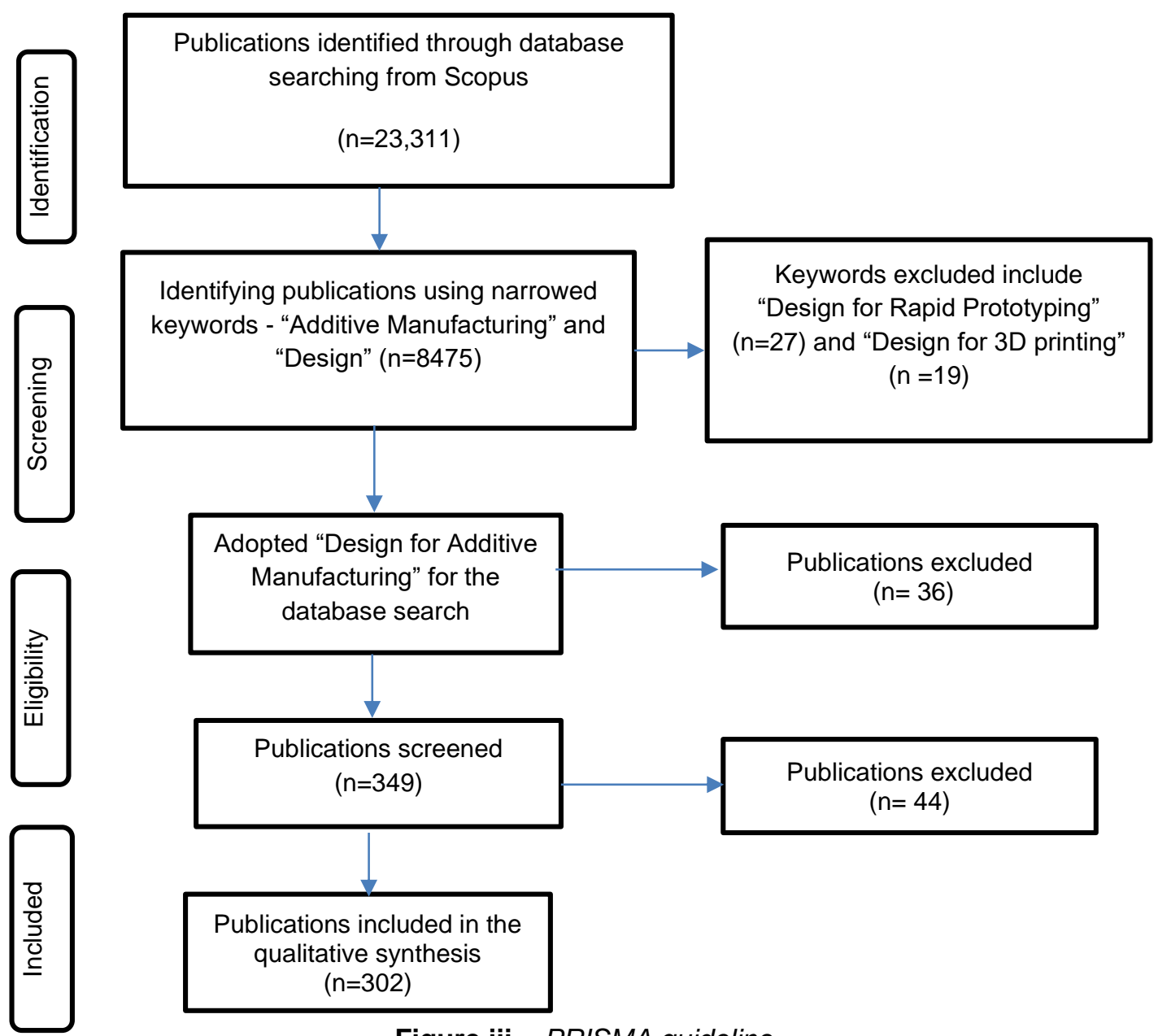

Figure iii - PRISMA guideline

A manual stratification process was employed to position the 302 articles into the classification boundaries set in this study. Because of the complex and subjective nature of the class boundaries, the articles were independently classified through a rigorous manual stratification process. Where articles covered more than one class boundary precedence was given to the more focused aspect of the article. All information for the analyses in the current work were exported from Scopus, including the authors and affiliations, publication data and Cite Scores, Citation Per Article, hindex, and Field Weighted Citation Impact (FWCI). ${ }^{1}$

\footnotetext{
${ }^{1} h$-index is measure obtained from a list of publications in descending order, and the value of $h$ is equal to the number of papers $(N)$ in the list that have $N$ or more citations. Field weighted citation impact is the ratio of the total citations received by the entity's output, and the total citation that would be expected based on the average of the research area. It is sourced directly from SciVal in Scopus.
} 


\section{Results}

The distribution of the examined articles according to the classifications DfAM Potential, Limitations, Specifics, and AM processes and parameters, are presented in table 1. A discussion on the topics of each class is provided in the research context section.

\subsection{Number of Publication and distribution}

The classification in figure ii based on this study shows the results for the four classes of studies on DfAM. The classes were further subclassified to show the precise areas where research has been conducted.

Table I: Distribution of articles according to DfAM classification

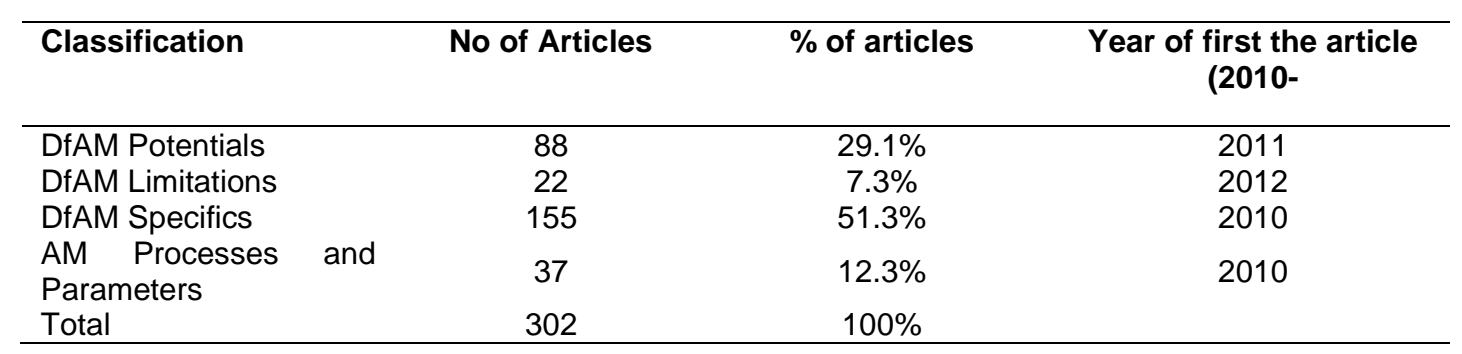

However, no subclassifications were given for the studies on AM processes and parameters. From the data, DfAM specifics was found to be addressed most frequently. Furthermore, studies that researched design methods have shown the highest percentage (21.8\%). This may be attributed to designers' curiosity to develop rules, guidelines, methods and tools that would harness the potentials of AM. Process cost, improvement in sustainability and reduced time to market are the least researched of the subclassifications.

Figure iv shows the distribution of the number of published articles from January 2010 till December 2020 when this analysis was conducted. The number of articles is not evenly distributed throughout the considered period. However, the data shows an exponential increase from 2015 onward. Additionally, 79\% of the articles were published between 2017 and 2020 and shows potential growth in the number of published papers (21) in the first quarter of 2020. Despite the focus of most research on DfAM specifics, it is hoped that going forward, more research will focus on understanding the potentials and limitations inherent in AM processes and develop the understanding of how to exploit them. 


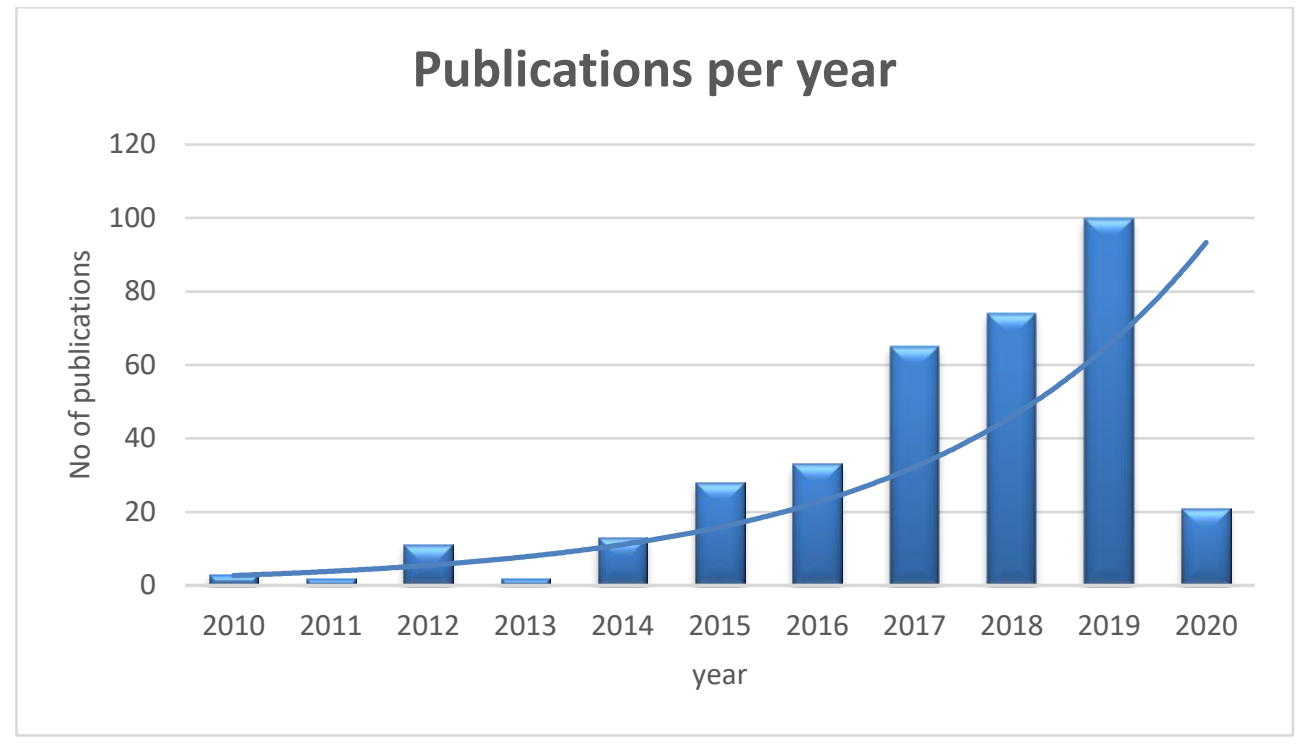

Figure iv: Number of Papers on DfAM published between January 2010 to December 2020

Overall, the data shows that academic literature is growing to accept and understand the impact of design on AM and its diffusion within the AM field. The current research exploited Scopus classification according to the document type (i.e. article, conference paper, review). The data distinguished 183 journal articles (60.6\% of the sample), 103 conference papers ( $34.1 \%$ of the sample), and 16 review papers $(5.3 \%$ of the sample). Table 2 illustrates the distribution of the different document types across the various classes. The reported values are proportional to the size of the sample.

Table II: Distribution of the articles on DfAM classification according to document typology (through the manual content analysis process)

\begin{tabular}{lccccc}
\hline $\begin{array}{l}\text { Document } \\
\text { Typology }\end{array}$ & $\begin{array}{c}\text { DfAM } \\
\text { Potentials }\end{array}$ & $\begin{array}{l}\text { DfAM } \\
\text { Limitations }\end{array}$ & $\begin{array}{c}\text { DfAM } \\
\text { Specifics }\end{array}$ & $\begin{array}{l}\text { AM } \\
\text { and Parameters }\end{array}$ & $\begin{array}{c}\text { Processes } \\
\text { Articles }\end{array}$ \\
\hline 5 & 15 & 89 & 22 & $183(60.6)$ \\
$\begin{array}{l}\text { Conference } \\
\text { Paper }\end{array}$ & 25 & 6 & 60 & 12 & $103(34.1)$ \\
Review & 6 & 1 & 6 & 3 & $16(5.3)$ \\
Total & 88 & 22 & 155 & 37 & $302(100)$ \\
\hline
\end{tabular}


The 302 documents were published in 104 different sources (as exported from Scopus): 72 journal outlets and 20 conference proceedings ${ }^{2}$. The largest number of documents were published in journals ( $64.9 \%$ of the total sample). These include 13 journal review articles and 3 conference review papers.

Information regarding the subject areas related to each journal paper where publications have been made in DfAM was provided by Scopus. Each publication source is associated with a subject area ${ }^{3}$. The sample documents cover a total of 11 different subject areas as shown in figure v. It is interesting to note that Scopus does not have a "Design" subject classification.

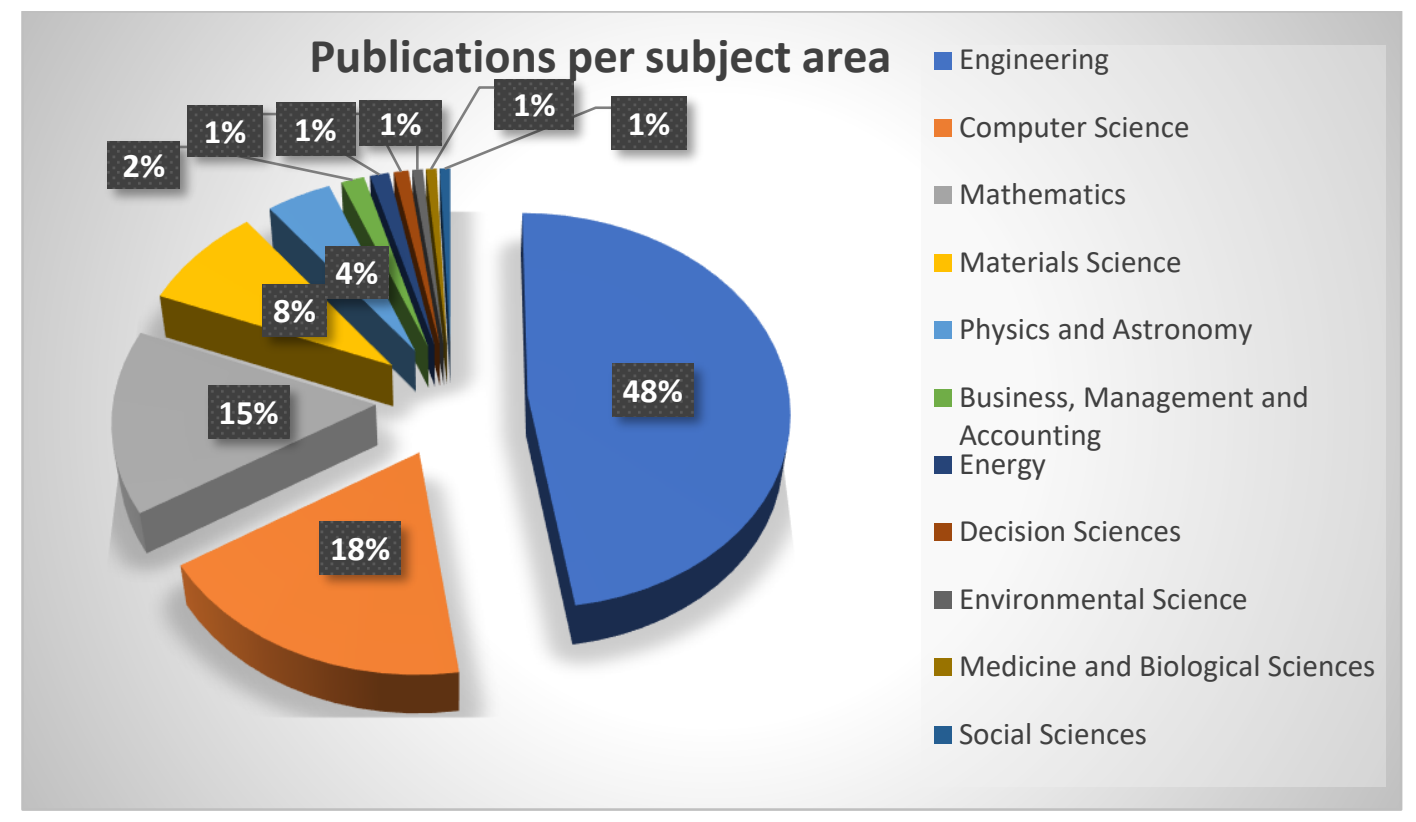

Figure v: Subject areas (as defined in Scopus) in DfAM

This suggests a multi-disciplinary approach to the study of DfAM. It also suggests that design is aimed at providing solutions for various disciplines (Lawson 2006) and that relevant knowledge can be generated from different fields of study. The most frequent areas are "Engineering" (48\%), "Computer Science" (18\%), "Mathematics" (15\%) and "Material Science" $(8 \%)$. In the past three years, the trend seems to have remained the same because publications in "Engineering" seems to have experienced a growth of $2 \%$ from 2019 to get to this current state.

\footnotetext{
2 Books, notes, and book series are excluded from this search

${ }^{3}$ Scopus identified 10 subject areas that cover the scientific field. They belong to the four major macro-areas: physical, social, health and life sciences.
} 
Table 3 lists the 10 publication outlets with the highest numbers of relevant papers (greater than seven) with their corresponding cite scores, number of citations, Citations Per Article (CPA) and Source Normalised Impact per Paper (SNIP) as reported in Scopus between 2014 to 2019. These outlets comprise six Journals and four conference proceedings. The six journals account for $23.5 \%$ of the examined documents and $8 \%$ of the total number of journal outlets. Similarly, $23.2 \%$ of the examined documents have been published in conference proceedings and accounted for $36.8 \%$ of the total proceedings published by Scopus. This suggests that there is a concentration of scientific publications dealing with DfAM. Furthermore, this shows that research in DfAM has been discussed more frequently at specific conferences.

Table III: Main Publication outlet for DfAM research

\begin{tabular}{|c|c|c|c|c|c|c|}
\hline Rank & Source & $\begin{array}{l}\text { Number of } \\
\text { Articles }\end{array}$ & $\begin{array}{l}\text { Cite } \\
\text { score }\end{array}$ & $\begin{array}{l}\text { No of } \\
\text { citations }\end{array}$ & $\begin{array}{l}\text { Citations per } \\
\text { Article }\end{array}$ & SNIP \\
\hline 1 & Procedia CIRP & 27 & 1.5 & 227 & 8.4 & 0.982 \\
\hline 2 & $\begin{array}{l}\text { Proceedings of the } \\
\text { International } \\
\text { Conference on } \\
\text { Engineering Design, } \\
\text { ICED }\end{array}$ & 24 & 0.00 & 39 & 1.6 & 0.00 \\
\hline 3 & $\begin{array}{l}\text { Journal of Mechanical } \\
\text { Design Transaction of } \\
\text { ASME }\end{array}$ & 20 & 2.85 & 180 & 9 & 1.414 \\
\hline 4 & $\begin{array}{l}\text { Rapid prototyping } \\
\text { Journal }\end{array}$ & 13 & 3.31 & 48 & 3.7 & 1.706 \\
\hline 5 & $\begin{array}{l}\text { Additive } \\
\text { Manufacturing }\end{array}$ & 11 & 7.73 & 46 & 4.2 & 2.938 \\
\hline 6 & $\begin{array}{l}\text { Proceedings of the } \\
\text { International } \\
\text { Conference on } \\
\text { Progress in Additive } \\
\text { Manufacturing }\end{array}$ & 11 & 0.00 & 9 & 0.8 & 0.00 \\
\hline 7 & Materials and Design & 10 & 5.16 & 233 & 23.3 & 2.424 \\
\hline 8 & $\begin{array}{l}\text { Virtual and Physical } \\
\text { Prototyping }\end{array}$ & 10 & 5.35 & 167 & 16.7 & 1.973 \\
\hline 9 & $\begin{array}{l}\text { Proceedings of the } \\
\text { ASME Design } \\
\text { Engineering Technical } \\
\text { Conference }\end{array}$ & 8 & 0.00 & 5 & 0.6 & 0.00 \\
\hline 10 & $\begin{array}{l}\text { International Journal } \\
\text { on Interactive Design } \\
\text { and Manufacturing }\end{array}$ & 7 & 1.31 & 18 & 2.6 & 1.192 \\
\hline
\end{tabular}

According to the outcomes from Scopus ${ }^{4}$, "Procedia CIRP" ranks first in terms of the number of articles followed by the "Proceedings of the International Conference on Engineering Design", which has one of the lowest scores in both cite score and SNIP

\footnotetext{
${ }^{4}$ Data obtained for analysis was predefined by Scopus between 2014 to >2019
} 
(according to Scopus). The "Journal of Mechanical Design Transactions of ASME" ranks third overall and leads with the most publications in a journal. The journal "Materials and Design" records the highest number of citations and the highest CPA, which shows that the contents are considered relevant to the DfAM research area.

VOSviewer (www.vosviewer.com) was used to create a network of sources that cover the intended timeframe (see figure vi). A full ${ }^{5}$ counting approach was used, and a weight of 1 was attributed to each link while the attraction and repulsion values are set to 5 and -8 respectively to enable the capture of the actual number of documents within the period under investigation.

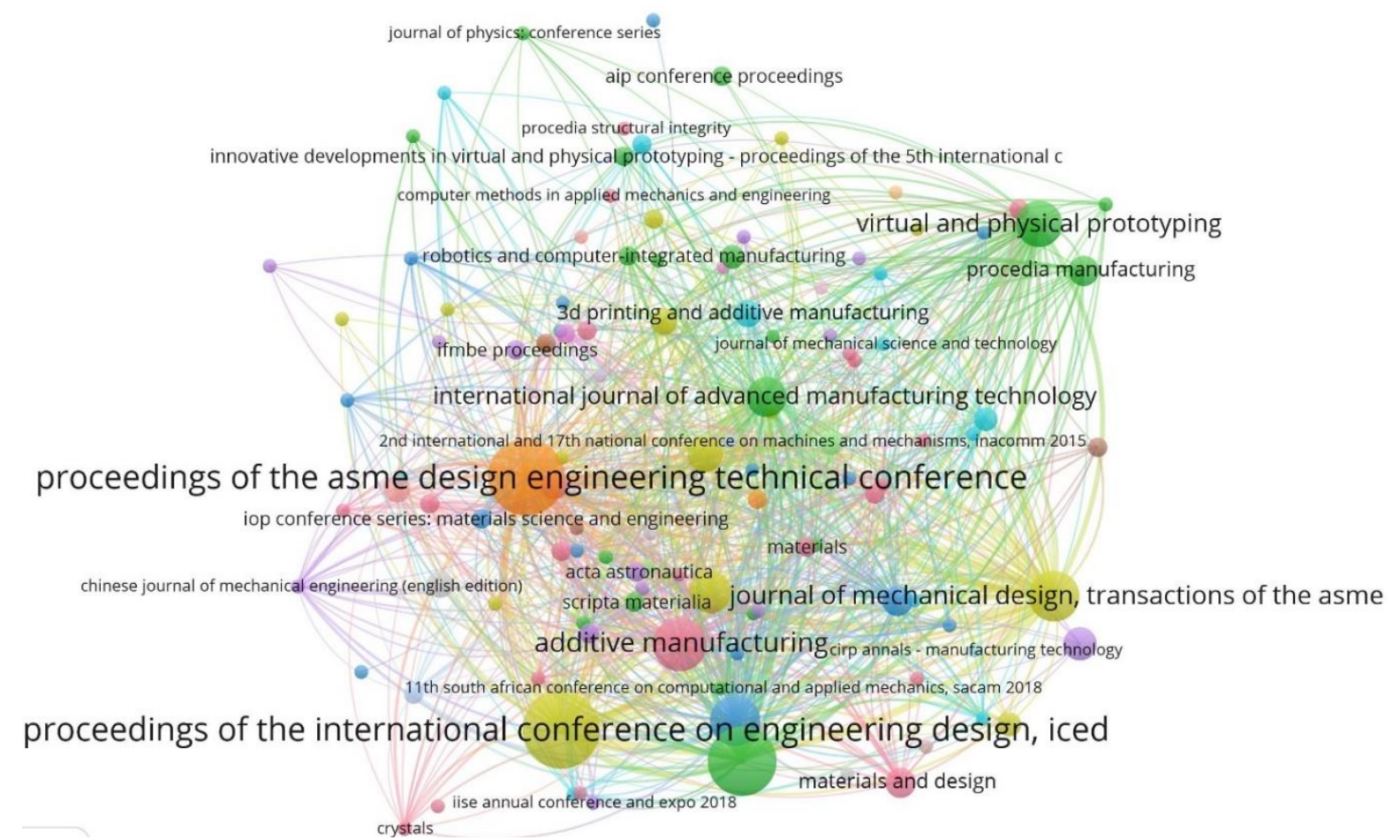

Figure vi - Network visualisation of sources based on citation

The outcome of the analysis shows that conferences have recorded more publications than journals, which affirms the outcome from Scopus. Proceedings of the International Conference on Engineering Design (ICED) leads with 36 publications and 90 links followed by Proceedings of the ASME Design Engineering Technical Conference (35) and Procedia CIRP (28). For journal publications, the journal "Additive Manufacturing" ranks highest with 17 outputs and 86 links, followed by the

\footnotetext{
${ }^{5}$ Full counting implies that each link represents a citation relationship between two countries; each link has a full weight of 1.
} 
Journal of Mechanical Transactions of the ASME and Rapid Prototyping Journal each having 15 outputs.

Table IV - Most Cited Articles in DfAM

\begin{tabular}{|c|c|c|c|c|c|c|c|c|}
\hline & Title & Authors & Year & $\begin{array}{l}\text { Scopus } \\
\text { Source title }\end{array}$ & $\begin{array}{l}\text { Volum } \\
\text { e }\end{array}$ & $\begin{array}{l}\text { Issu } \\
\text { e }\end{array}$ & $\begin{array}{l}\text { Page } \\
\mathrm{s}\end{array}$ & $\begin{array}{l}\text { Citation } \\
s\end{array}$ \\
\hline 1. & $\begin{array}{l}\text { Optimal topology } \\
\text { for additive } \\
\text { manufacture: A } \\
\text { method for } \\
\text { enabling additive } \\
\text { manufacture of } \\
\text { support-free } \\
\text { optimal structures }\end{array}$ & $\begin{array}{l}\text { Leary, M; Merli, } \\
\text { L;Torti, } \\
\text { F.;Mazur, } \\
\text { M.;Brandt, M. }\end{array}$ & 2014 & $\begin{array}{l}\text { Materials and } \\
\text { Design }\end{array}$ & 63 & - & $\begin{array}{l}678- \\
690\end{array}$ & 136 \\
\hline 2. & $\begin{array}{l}\text { Additive } \\
\text { manufacturing- } \\
\text { enabled design } \\
\text { theory and } \\
\text { methodology: a } \\
\text { critical review }\end{array}$ & $\begin{array}{l}\text { Yang, S.;Zhao, } \\
\text { Y.F }\end{array}$ & 2015 & $\begin{array}{l}\text { International } \\
\text { Journal of } \\
\text { Advanced } \\
\text { Manufacturin } \\
\text { g Technology }\end{array}$ & 80 & - & $\begin{array}{l}327- \\
342\end{array}$ & 121 \\
\hline 3. & $\begin{array}{l}\text { Selective laser } \\
\text { melting (SLM) of } \\
\text { AISi12Mg lattice } \\
\text { structures }\end{array}$ & $\begin{array}{l}\text { Leary, } \\
\text { M.;Mazur, } \\
\text { M.;Elambasseril } \\
\text {, J.;McMillan, } \\
\text { M.;Chirent, } \\
\text { T.;Sun, Y.;Qian, } \\
\text { M.;Easton, } \\
\text { M.;Brandt, M. }\end{array}$ & 2016 & $\begin{array}{l}\text { Materials and } \\
\text { Design }\end{array}$ & 98 & - & $\begin{array}{l}344- \\
357\end{array}$ & 106 \\
\hline 4. & $\begin{array}{l}\text { Design strategies } \\
\text { for the process of } \\
\text { additive } \\
\text { manufacturing }\end{array}$ & $\begin{array}{l}\text { Klahn, } \\
\text { C.;Leutenecker, } \\
\text { B.;Meboldt, M. }\end{array}$ & 2015 & $\begin{array}{l}\text { Procedia } \\
\text { CIRP }\end{array}$ & 36 & - & $\begin{array}{l}230- \\
235\end{array}$ & 69 \\
\hline 5. & $\begin{array}{l}\text { A new } \\
\text { methodological } \\
\text { framework for } \\
\text { design for } \\
\text { additive } \\
\text { manufacturing }\end{array}$ & $\begin{array}{l}\text { Kumke, M.; } \\
\text { Watschke, H.; } \\
\text { Vietor, T. }\end{array}$ & 2016 & $\begin{array}{l}\text { Virtual and } \\
\text { Physical } \\
\text { Prototyping }\end{array}$ & 11 & 12 & $\begin{array}{r}481 \\
- \\
493\end{array}$ & 67 \\
\hline
\end{tabular}

The information in table 4 shows the 5 most cited papers in DfAM research. 4 out of 5 papers address DfAM specifics, which confirms previous results from both Scopus and VOSviewer. Furthermore, their years of publication reveal that 2014 to 2016 were strategic years when the core knowledge to develop the research field was formed. This is assumed to have led to a 100\% growth in research output in 2017 from 2016.

\subsection{The geography of scientific publications:}

Data from the institutions affiliated with the authors of the examined articles have been captured as presented by Scopus ${ }^{6}$. This enables an understanding of the geographical location of documents in over 100 institutions within 33 countries around the world (14 in Europe, 12 in Asia, 3 in North and south America, 2 in Australia and 2 in Africa). Table 4 shows the number of articles by the geographical location of the authors'

\footnotetext{
${ }^{6}$ Data obtained for analysis was predefined by Scopus between 2014 to >2019
} 
institutional affiliations. Europe and North America are the two continents with the largest number of published articles ( $41 \%$ and $35 \%$ of the total sample, respectively), followed by Asia 17.7\%, Australia 5\%, and Africa 1.5\%.

Table V. List of countries and number of publications

$\begin{array}{lclc}\text { Country } & \text { No of Publications } & \text { Country } & \text { No of Publications } \\ \text { United States } & & & \\ \text { Germany } & 96 & \text { Iran } & 4 \\ \text { Italy } & 35 & \text { India } & 4 \\ \text { United Kingdom } & 34 & \text { Norway } & 4 \\ \text { France } & 33 & \text { New Zealand } & 3 \\ \text { Singapore } & 31 & \text { Denmark } & 3 \\ \text { Canada } & 22 & \text { Brazil } & 3 \\ \text { Switzerland } & 22 & \text { Spain } & 2 \\ \text { China } & 18 & \text { Croatia } & 2 \\ \text { Sweden } & 14 & \text { South Africa } & 2 \\ \text { South Korea } & 10 & \text { Swaziland } & 2 \\ \text { Australia } & 10 & \text { Pakistan } & 2 \\ \text { Netherlands } & 9 & \text { Others } & 1 \\ \end{array}$

The United States and Germany account for the largest number of articles, with 96 and 35 papers, respectively. The other most frequent countries are Italy (34), United Kingdom (33), France (31), Singapore (22) Canada (22), Switzerland (18) and China (14). The geographical distribution of the published papers is presented in a map in figure vii.

7 Others as stated in the table represent countries with only one publication and they include: Egypt, Israel, Japan, Lebanon, Russian Federation, Saudi Arabia, Slovenia, Romania, Vietnam, and Taiwan. (as provided in Scopus). 


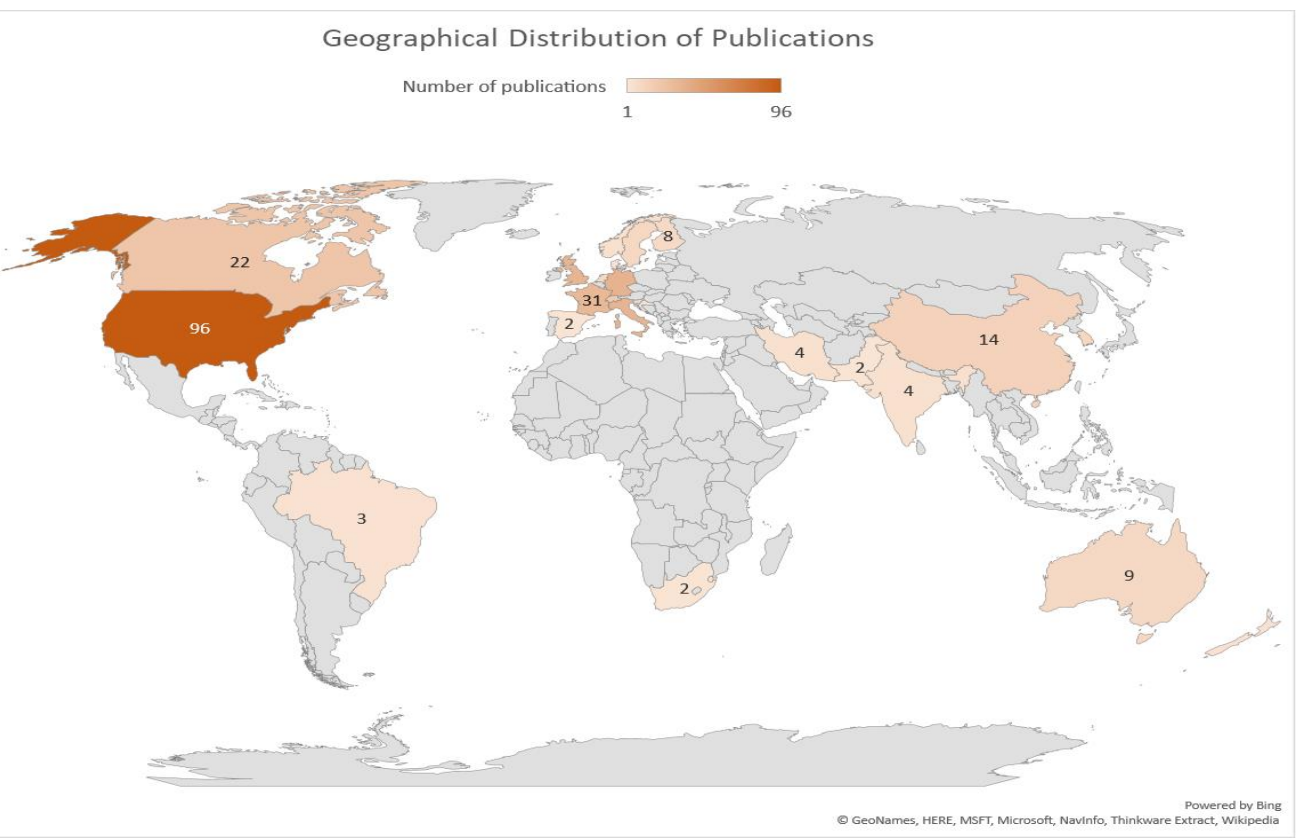

Figure vii: Geographical distribution of publications on DfAM

To further understand the relationship between countries, a citation analysis was conducted. With this analysis, the total number of citations received by all the documents published in a country and their links to other countries were retrieved.

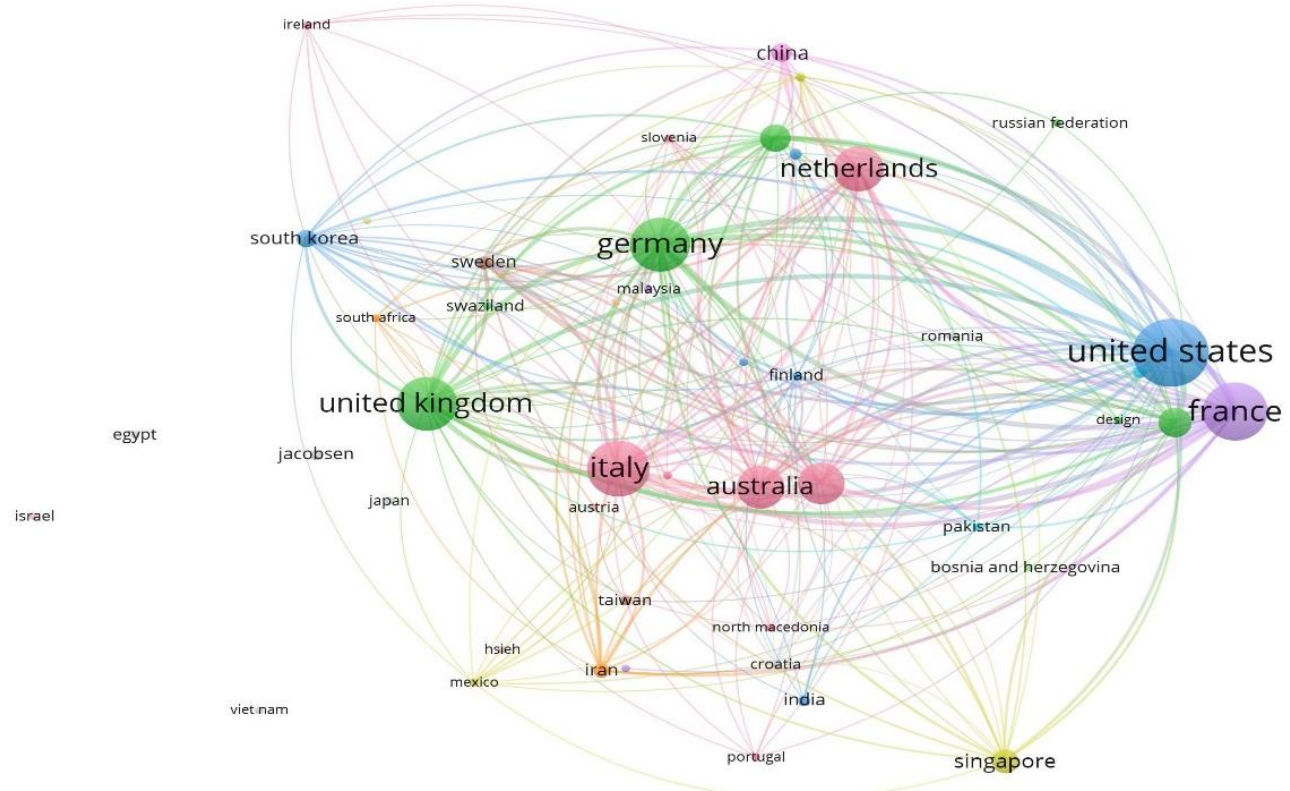

Figure viii - Network visualisation of citations between countries 
A network analysis was created (see figure viii) using a Full Counting approach ${ }^{8}$ with the attraction and repulsion values set to 5 and -8 respectively. The USA ranks first with 1282 citations linked to 31 countries. With 916 citations, France ranks second and is linked with the other 32 countries. Italy is mostly linked to 29 other European countries with a total of 843 citations. The analysis further establishes that the number of publications in a country does not determine the number of citations the publication receives. The relevance of the publications and the ability to develop knowledge that could be built upon for future research are potential reasons why countries receive more citations than others.

The data in Table VI presents a list of the top 11 universities ranked according to their number of published articles in DfAM (113 articles, 37.4\%) as shown in Scopus ${ }^{9}$. This depicts a relatively even distribution of publications within a small number of universities in comparison with the total number of universities involved in this research area. Pennsylvania State University ranks first with 19 publications (6.3\%), followed by ETH Zurich and Singapore University of Technology and Design (4.6\%) and Georgia Institute of Technology (4\%). Politecnico di Milano with 8 publications attained the highest number of citations (207) while ETH Zurich has the highest FieldWeighted Citation Impact.

\footnotetext{
8 Full counting implies that each link represents a citation relationship between two countries; each link has a full weight of 1. 9 Analysis was subject to the data as represented on the table and not the overall sample.
} 
Table VI: List of 10 most active schools and their publication ranking in DfAM

\begin{tabular}{|c|c|c|c|c|c|c|}
\hline Institution & Country & $\begin{array}{l}\text { Publications } \\
\text { in this } \\
\text { Research } \\
\text { Area }\end{array}$ & $\begin{array}{l}\text { Publications } \\
\text { in this } \\
\text { Research } \\
\text { Area } \\
\text { (growth \%) }\end{array}$ & Citations & $\begin{array}{l}\text { Citations } \\
\text { per } \\
\text { Article } \\
\text { (CPA) }\end{array}$ & $\begin{array}{l}\text { Field- } \\
\text { Weighted } \\
\text { Citation } \\
\text { Impact }\end{array}$ \\
\hline $\begin{array}{l}\text { 1. Pennsylvania } \\
\text { State University } \\
\text { 2. Swiss Federal }\end{array}$ & $\begin{array}{l}\text { United } \\
\text { States } \\
\text { Switzerland }\end{array}$ & 19 & $(9.0 . . . .6)$ & 122 & 6.4 & 3.72 \\
\hline $\begin{array}{l}\text { 2. Swiss Federal } \\
\text { Institute of } \\
\text { Technology Zurich }\end{array}$ & & 14 & 100 & 180 & 12.9 & 4.81 \\
\hline $\begin{array}{l}\text { 3. Singapore } \\
\text { University of } \\
\text { Technology and } \\
\text { Design }\end{array}$ & Singapore & 14 & 300 & 50 & 3.6 & 0.92 \\
\hline $\begin{array}{l}\text { 4. Georgia Institute of } \\
\text { Technology } \\
\text { 5. Royal Melbourne }\end{array}$ & $\begin{array}{l}\text { United } \\
\text { States } \\
\text { Australia }\end{array}$ & 12 & -50 & 114 & 9.5 & 3.68 \\
\hline $\begin{array}{l}\text { Institute of } \\
\text { Technology } \\
\text { University }\end{array}$ & & 11 & 100 & 308 & 28 & 2.24 \\
\hline 6. Nanyang & Singapore & & & & & \\
\hline $\begin{array}{l}\text { Technological } \\
\text { University }\end{array}$ & & 10 & 100 & 15 & 1.5 & 0.66 \\
\hline $\begin{array}{l}\text { 7. Polytechnic } \\
\text { University of Milan }\end{array}$ & Italy & 8 & 0 & 207 & 25.9 & 2.28 \\
\hline $\begin{array}{l}\text { 8. Arts et Métiers } \\
\text { ParisTech }\end{array}$ & France & 8 & - & 97 & 12.1 & 1.37 \\
\hline $\begin{array}{l}\text { 9. University of } \\
\text { Texas at Austin }\end{array}$ & $\begin{array}{l}\text { United } \\
\text { States }\end{array}$ & 7 & 0 & 59 & 8.4 & 4.92 \\
\hline $\begin{array}{l}\text { 10. Technical } \\
\text { University of } \\
\text { Braunschweig }\end{array}$ & Germany & 6 & - & 94 & 15.7 & 3.05 \\
\hline $\begin{array}{l}\text { 11. Loughborough } \\
\text { University }\end{array}$ & $\begin{array}{l}\text { United } \\
\text { Kingdom }\end{array}$ & 4 & - & 25 & 6.3 & 2.81 \\
\hline
\end{tabular}

The sample represented in table $6^{10}$ shows that 9 authors out of 18 are from North America which covers $50 \%$ of the sample presented in the table and comprise 8 authors from the USA and 1 from Canada. Europe ranks second with 5 authors $(27.8 \%)$ with France, Switzerland, Italy having 1 author each and 2 authors from Germany. Australia covers $16.7 \%$ of the sample with 3 authors and Asia covers $5.6 \%$ of the represented sample with 1 author from Singapore.

South America and Africa had no representations in the sample population. Some of this may be accounted for by publishing in languages other than English. However, even with the inadequate sample representation, the available data shows that most authors are predominantly based in North America. This may suggest that $A M$ is widely accepted in the continent and so, significant numbers of researchers are interested in exploiting the potentials of AM technologies within that region. Africa and

\footnotetext{
10 Analysis was subject to the data as represented on the table and not the overall sample.
} 
South America may represent a fertile ground for innovative ideas in Additive Manufacturing and more specifically, DfAM. Despite the high concentration of publications, the available data reveals that 3 out of the 11 institutions have recorded no growth within the considered timeframe ${ }^{11}$. Amongst which are the Georgia Institute of Technology, Politecnico di Milano and the University of Texas at Austin. While the Singapore University of Technology and Design records the highest growth, ETH Zurich, RMIT and Nanyang Technological University recorded stable growth of $100 \%$ in publication output. The highest CPA was recorded by RMIT (28), followed by Politecnico di Milano (25.9) and Technical University of Braunschweig (15.7). This follows the trend in the number of citations except for ETH Zurich ranking third with 180 citations. Institutions with the highest number of publications have received as high CPA values as others. This may suggest that their works are relevant and have provided a foundation for further studies.

\subsection{Citations, co- authorships, and keywords}

In this section, the results of the bibliometric analysis based on authors' citations, coauthorships and keywords are presented. The 100 most active authors in DfAM research were presented in Scopus. However, we limited our sample to authors with 5 publications or more, presented in table 6 . Rosen tops the chart with 16 publications and Simpson has 13 publications, which span across the various classes of DfAM (potentials, limitations, and specifics) and citations of 145 and 112 respectively. Meisel follows with 10. Brandt and Leary each have 308 citations while Leary leads with an average Citation Per Publication of 34.2. It is interesting to note that despite their number of citations and Citations Per Publication, they recorded lower Field Weighted Citation Impact (FWCI) compared with Seepersad who has fewer outputs (6) but the highest Weighted Impact of 5.74. It can be implied that Seepersad's outputs have established some fundamental knowledge such as design rules and guidelines for AM processes. These aspects of DfAM knowledge have the potential to impact how AM processes are deployed for industrial applications and may have been cited by other works that have either made significant impacts or would make impacts in the future. However, the use of the appropriate keyword can significantly impact the visibility of articles. Therefore, it is recommended that authors should carefully consider the use

\footnotetext{
${ }^{11}$ Analysis was subject to the data as represented on the table and not the overall sample.
} 
of keywords that focus on DfAM related work within the article title, abstract, keywords and content to increase publication visibility in database searching.

The difference between the highest and lowest values of authors' $\mathrm{FWCI}$ as presented in the table is 5.32 and the difference in the authors' number of publications is 11 . This comparison suggests that research has not established foundational knowledge such as in the areas of materials, DfAM limitations, AM process and parameters, etc. These DfAM knowledge aspects are significant because they address the complexities posed using AM for both industrial and research applications. Therefore, as more research focus on these areas, more approaches to exploit AM potentials and overcome its limitations will be uncovered, thus, other researchers can build on this existing knowledge to make a significant impact in the DfAM field.

Table VII: List of most active authors in the DfAM field

\begin{tabular}{|c|c|c|c|c|c|}
\hline Name & $\begin{array}{l}\text { Scholarly } \\
\text { Output in this } \\
\text { Research } \\
\text { Area }\end{array}$ & $\begin{array}{l}\text { Citations in } \\
\text { this } \\
\text { Research } \\
\text { Area }\end{array}$ & $\begin{array}{l}\text { Citations } \\
\text { per } \\
\text { Publication }\end{array}$ & $\begin{array}{l}\text { Field- } \\
\text { Weighted } \\
\text { Citation } \\
\text { Impact }\end{array}$ & $\begin{array}{l}\text { h- } \\
\text { index }\end{array}$ \\
\hline Rosen, David W. & 16 & 145 & 9.1 & 2.99 & 38 \\
\hline $\begin{array}{l}\text { Simpson, Timothy W. } \\
\text { Meisel, Nicholas }\end{array}$ & 13 & 112 & 8.6 & 4.65 & 51 \\
\hline Alexander & 10 & 66 & 6.6 & 1.47 & 9 \\
\hline Brandt, M. & 10 & 308 & 30.8 & 2.46 & 35 \\
\hline Leary, Martin & 9 & 308 & 34.2 & 2.74 & 19 \\
\hline Ko, Hyunwoong & 8 & 18 & 2.3 & 1.29 & 3 \\
\hline Miller, Scarlett Rae & 7 & 13 & 1.9 & 1.57 & 12 \\
\hline Segonds, Frédéric & 6 & 82 & 13.7 & 1.33 & 9 \\
\hline Moon, Seung Ki & 6 & 10 & 1.7 & 0.42 & 18 \\
\hline Shea, Kristina & 6 & 21 & 3.5 & 2.22 & 25 \\
\hline Watschke, Hagen & 6 & 94 & 15.7 & 3.05 & 5 \\
\hline $\begin{array}{l}\text { McMillan, Matthew Leslie } \\
\text { Seepersad, Carolyn }\end{array}$ & 6 & 126 & 21 & 1.98 & 4 \\
\hline Conner & 6 & 59 & 9.8 & 5.74 & 29 \\
\hline Vietor, Thomas & 6 & 94 & 15.7 & 3.05 & 8 \\
\hline Witherell, Paul William & 5 & 16 & 3.2 & 2.39 & 12 \\
\hline $\begin{array}{l}\text { Graziosi, Serena } \\
\text { Zhao, Yaoyao Fiona }\end{array}$ & 5 & 24 & 4.8 & 1.12 & 7 \\
\hline Fiona & 5 & 144 & 28.8 & 2.24 & 18 \\
\hline Prabhu, Rohan Sunil & 5 & 9 & 1.8 & 1.79 & 3 \\
\hline
\end{tabular}


Therefore, research in DfAM should be conducted with rigour, built on existing knowledge while establishing a solid foundation for further works, which should have a substantial impact on the research area.

To increase the understanding of co-authorship, a network of co-authorship was created using VOSViewer ${ }^{12}$. The 836 authors ${ }^{13}$ were grouped into 170 clusters with 1 to 24 authors. The current visual output is achieved by setting the attraction and repulsion values to 3 and -5 respectively in VOSviewer. Nearly $64 \%$ of the clusters have less than 5 authors (13 are single authors, 36 contain two authors, 28 have three authors and 31 connect four authors). Clusters with more than ten authors represent about $26 \%$ of the sample. In figure ix, we report a subsample of clusters representing all the authors, their links, and clusters shown using different colours.

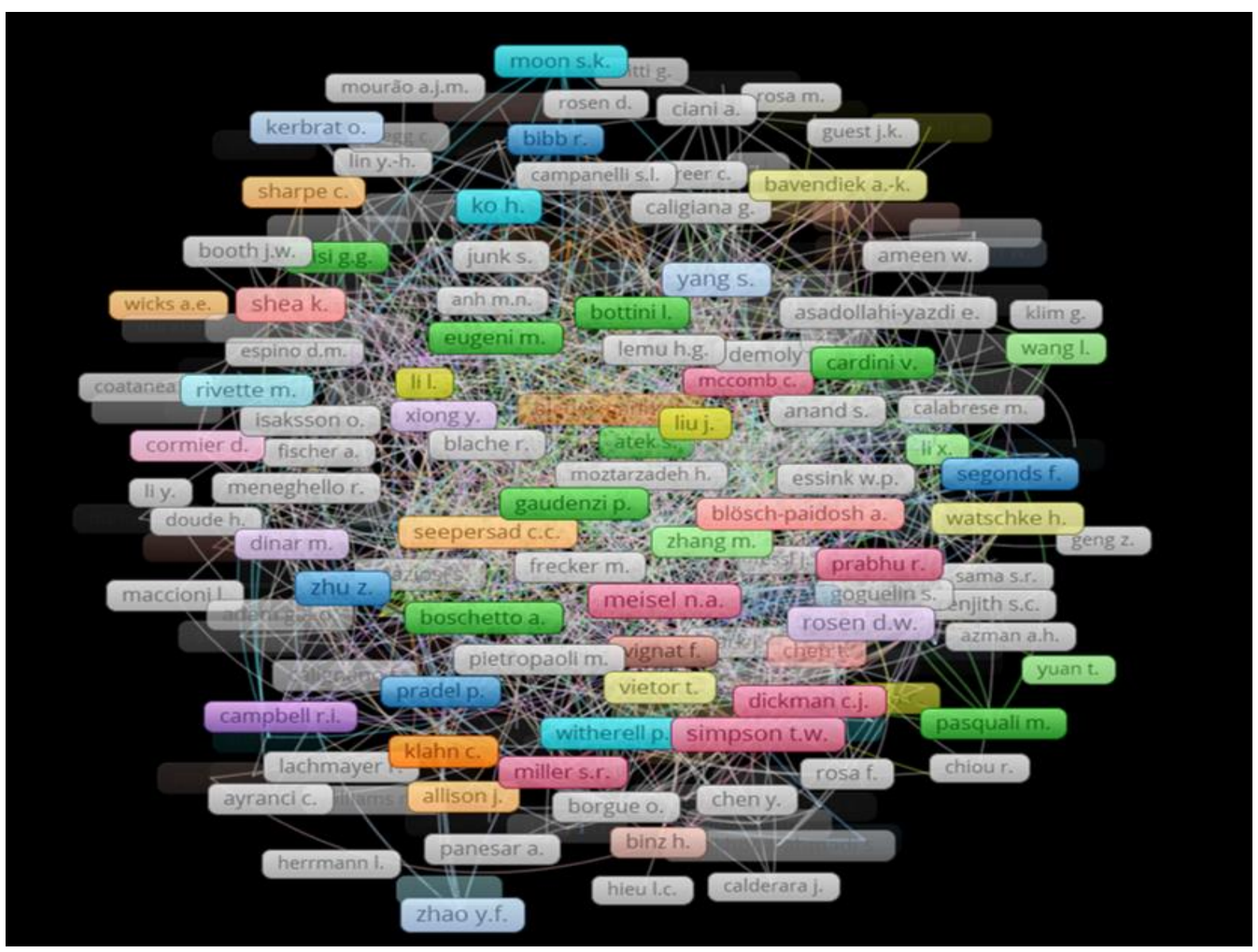

12 VOSviewer is a software tool for constructing and visualising bibliometric networks

13 The data on affiliation refers to the institution and the corresponding countries at the time of this publication. The analysis provided on the number of papers reflects those of the examined papers and the table is as provided by Scopus and considers double count multiple authors from the same continent/country/institution in the same publication 
Figure ix: A network of co-authorship and collaboration

The largest clusters (in red) connect 24 different researchers and are the most collaborative authors in the analysed sample. The second-largest cluster (in green) contains a connection of 22 researchers and the cluster in blue connects 21 authors. The output from the network of co-authorship shows that the most frequent collaborations within the identified sample are between Simpson, Dickman and Meisel in the largest cluster, with Simpson ranking highest in the number of co-authors (22), Dickman (10) and Meisel (10). Likewise, Gaudienzi, Pollice, Eugeni and Cardini are identified as the frequent collaborators in the second-largest cluster; Gaudienzi ranking highest with 21 links, Pollice (20), Eugeni and Cardini ranking third with 19 links. In the third-largest cluster, frequent collaboration is seen between Segonds, Anwer, D'antonio, Abed and Laverne with Segonds ranking highest (17) followed by Anwer (10) and then Laverne (7). It is observed that the majority of authors from the same cluster have the same institutional affiliation, and hence we infer that they work as a team or research group. Similarly, this shows that DfAM research is mostly being conducted within specific localised geographical areas and suggests there is compatatively little collaboration across instiutions or across geographical regions.. For better visualisation, figure $\mathrm{x}$ presents an exploded version showing the links between the mentioned authors above. As a recommendation, for more effective DfAM knowledge development, cross-institutional and international collaboration should be encouraged and facilitated through structured global networks of DfAM researchers, academics and industry practitioners. Global DfAM networks could utilise seminars, workshops, DfAM education events and design competitions through which knowledge development, dissemination, and exchange can be achieved. Moreover, continents and countries can mirror the events of the global network to contextualise the adoption of $A M$ in their geographic location. 


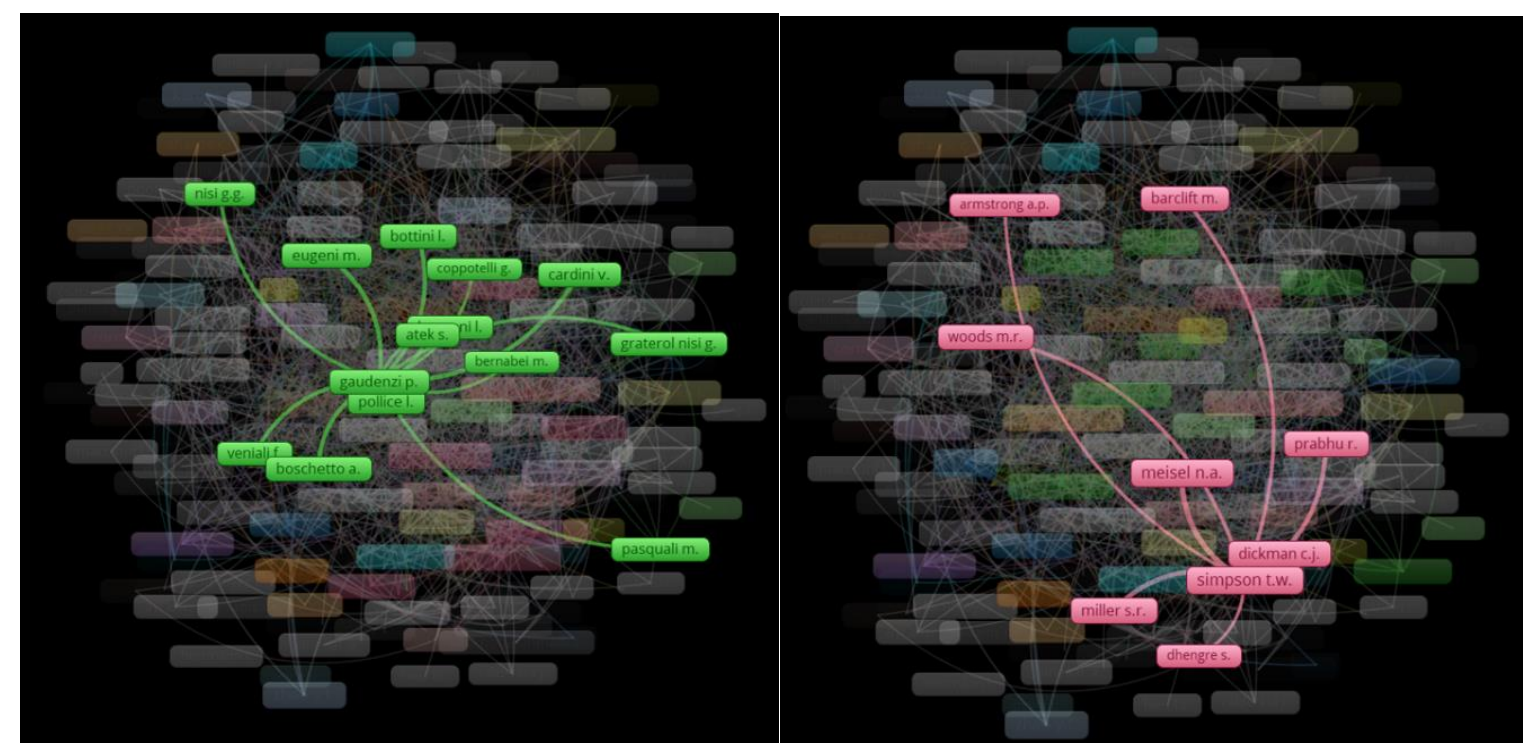

Figure x: An exploded view of the most collaborative networks

\subsection{Keywords Analysis}

The outcome of the network analysis as shown in figure xi, revealed the authors' most frequently occurring keywords in the analysed literature. As expected "Design for Additive Manufacturing" leads with 139 occurrences linked to 348 keywords. "Additive Manufacturing" follows with 136 occurrences which are linked to 305 keywords and topology optimisation having 28 occurrences linked to 74 keywords. 


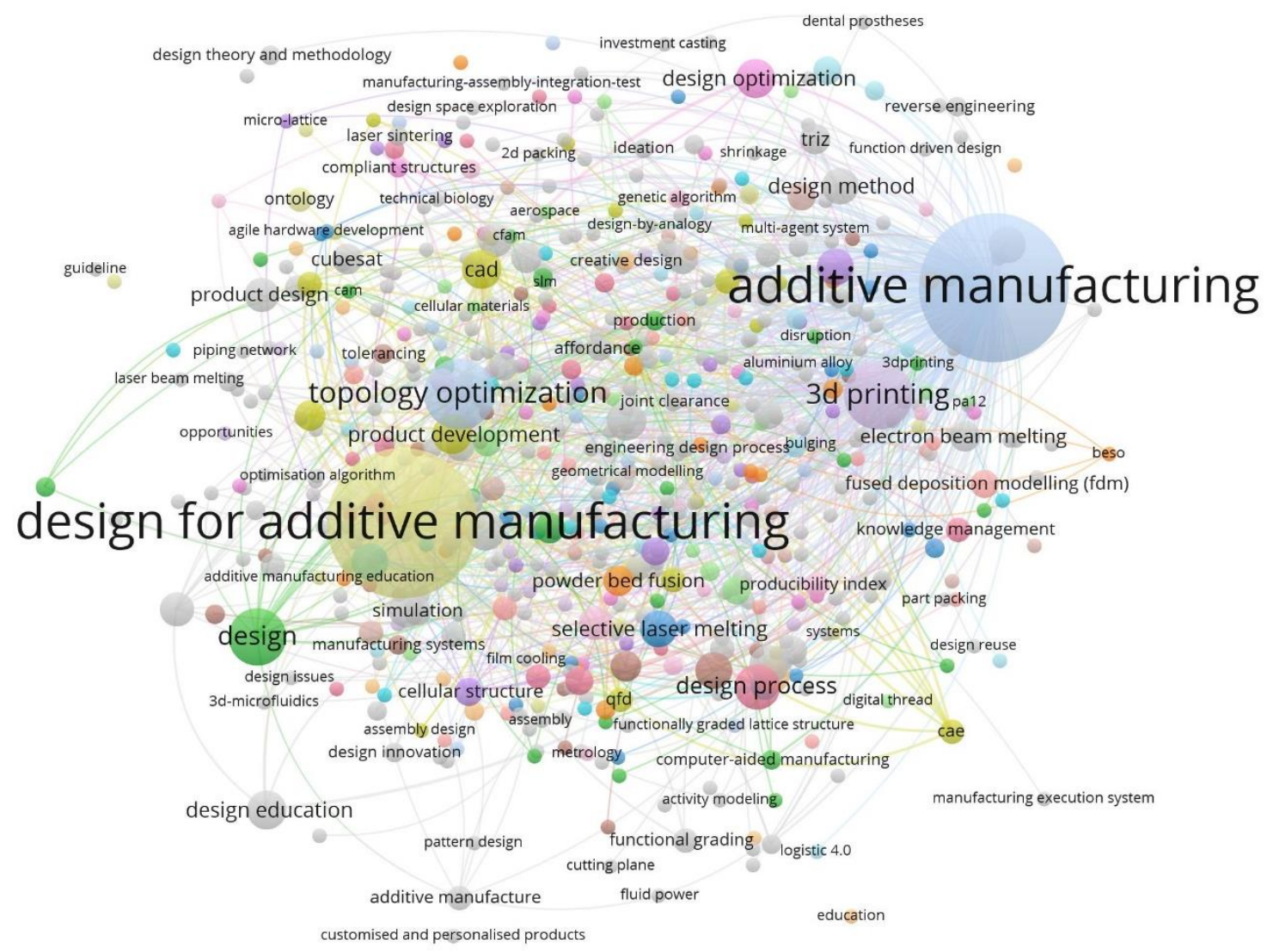

Figure xi: Network Visualisation of keyword occurrence

\section{Discussion and areas of future research}

The identified publications were analysed by classification into "DFAM potentials", "DfAM limitations", "DfAM specifics" and "AM processes". Studies on "DfAM Specifics" which accounts for $53.5 \%$ have been addressed more frequently with Design Methods next at $23.5 \%$. Studies on "DfAM limitations" and "AM processes" were found to be the least investigated (12.5\% and $8.5 \%$ respectively). This finding reveals the areas where DfAM literature might be underdeveloped. This disparity between the reported studies does not help in synthesising the developed knowledge, as DfAM requires specific competencies and know-how to be adequately diffused and accepted across academic and within industry.

\subsection{The outcomes of keyword analysis}

The Keyword analysis provided more understanding of the four classifications presented in fig $i$, unravelling the concentration of research in DfAM and possible research agenda from the existing body of knowledge. Furthermore, it validates the 
findings from the review conducted from which the classification was developed (see figure xii)

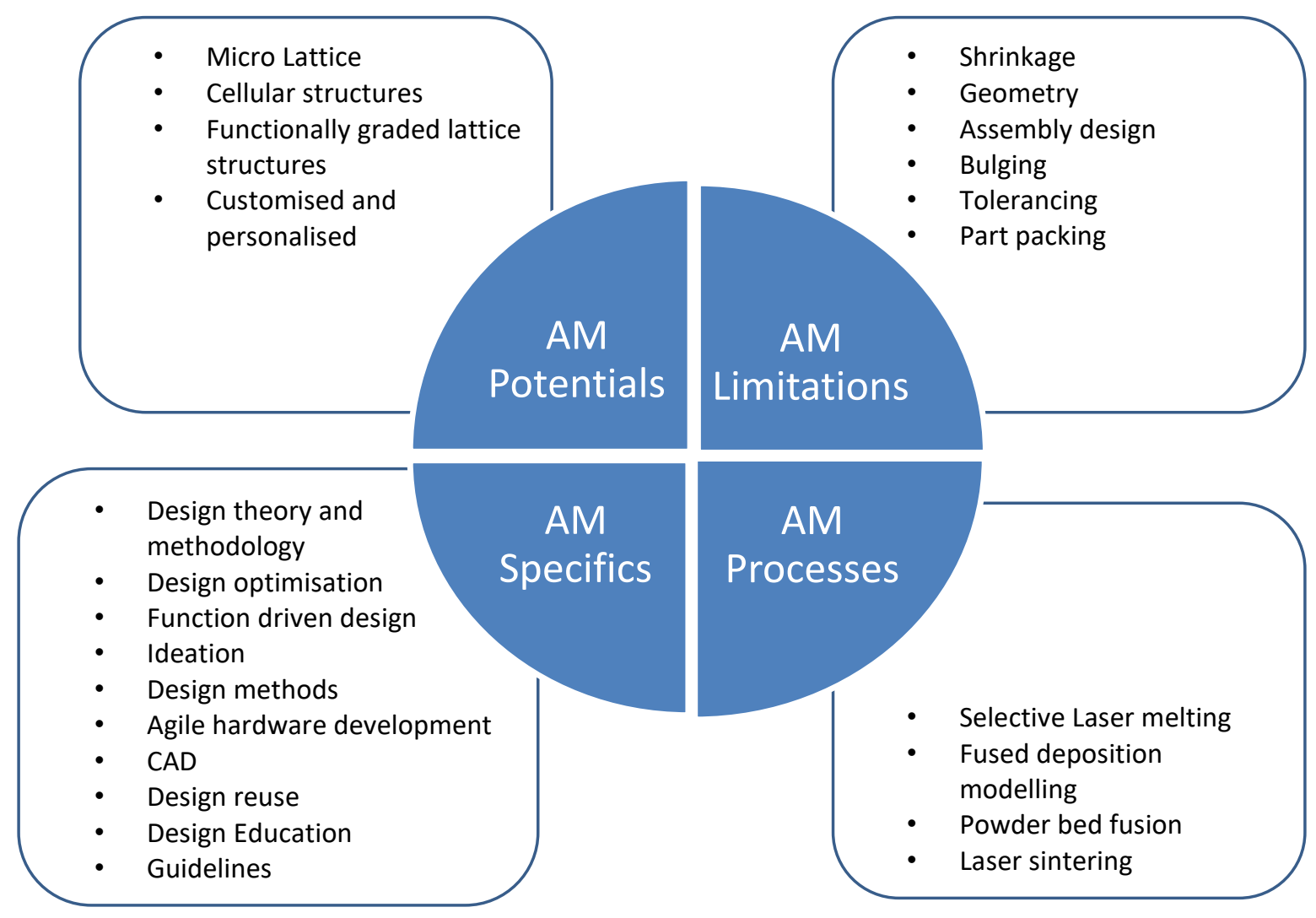

Figure xii: Outcome from keyword analysis

For AM potentials, the outcome shows that hierarchical complexity has been predominantly researched under keywords such as micro-lattice (Lim, Park and Park, 2018), the design of cellular structure (Opgenoord and Willcox, 2019; Vega-Moreno et al., 2020), and functionally graded lattice structures (Nguyen and Choi, 2020). Although earlier works laid the foundation for research directions in cellular structures (Tamburrino, Graziosi and Bordegoni, 2018), more research is needed in the development of new functionalities and properties beyond lightweight, by approaches that integrate design, materials, and $A M$ technologies. Moreover, as the interest in lattice structures continues to develop, research should focus on developing novel unit cell topologies through optimisation, and novel approaches that account for hierarchical complexities (Hanks et al., 2020). Furthermore, research should focus on 
non-compressive behaviours of lattice structures such as torsion, vibration, cyclic and fatigue loading and address the construction of support segments with periodic and non-periodic cellular structures to reduce residual stress (Graziosi et al., 2020). Regarding material complexity, the analysis of the keywords corroborates initial findings from the classification that materials have not been substantially studied. However, most recent studies have focused on how to exploit the material capabilities in the use of AM technologies. Li et al., (2021) studied the material growth pattern using a force flow technique, Kuschmitz et al., (2021) utilised a machine learning approach to compute acoustic material parameters (Biot parameters) from the material's micro-scale geometry and the application of multi-material capabilities of AM to the development of elastomers and electrically conductive polymers (Watschke et al., 2021). Future work should focus on how to control anisotropy through process planning to achieve dual control of material geometry and performance. Furthermore, efforts should be put into developing a novel material structures that match material strength and part stresses.

As customisation and personalisation are vital potentials offered by $A M$, research in DfAM should explore the use of design methods such as user-centred design, codesign, and inclusive design to understand the influence of users in the design of additively manufactured end-use products. An attempt at studying the impact of users in mass customisation of AM products was performed by Spallek and Krause, (2016), however, their focus was on vascular models. Therefore, there is a need to research the customisation and personalisation of end-use products for various industrial applications. Generally, research should focus on potential research areas which were not captured in the keyword analysis such as AM technologies, sustainability issues, cost implications, and additional product values. Additional product values such as product performance, product multifunctionality, reduced costs, etc., highlight the benefits from the product due to the implementation of $A M$ in the product manufacturing Kumke et al., (2018).

Regarding AM limitations, some discrepancies exist between the captured keywords and the limitations captured in the literature. This may be due to inconsistency or misinterpretation in the use of terminologies. Shrinkage and bulging of printed parts have been studied by Martusevich and Sen, (2017), Fessl et al., (2018), Ullah, Akmal, S. V. A. Laakso, et al., (2020) and Ullah et al., (2020) as manufacturability and post- 
processing issues. To tackle such manufacturability and post-processing issues, and due to the complex and intricate geometries of most AM parts, future research should focus on automating the post-processing activities. In addition to tackling manufacturability issues, automating post-processing activities has the potential to reduce the overall manufacturing cost and lead-time. AM Limitations that deal with Part decomposition (PD) and assembly have been studied by Battaïa et al., (2018) and Sossou et al., (2018). Although, PD has not gained much traction in DfAM, Oh, Zhou and Behdad, (2018) proposed that PD has the capability to increase AM productivity for mass production. Future work should focus on process time, process quality and material cost rather than simply the "printability" of the product. Furthermore, research should also develop novel decomposition methods and applying conventional design methodologies in the design for assembly (Oh, Zhou and Behdad, 2018). Geometric tolerancing is important in the DfAM context because it determines the assemblability and final quality of AM parts. Whilst there have been many studies on AM process optimisation that aim to improve final tolerances there appear to be very few studies that have attempted to study the application of design stage solutions to tolerancing in AM processes. Seepersad et al.,(2012) conducted series of experiments to determine the tolerancing of various types of fabricated features in commercially available SLS machines. Furthermore, a work by Rupal et al., (2020) studied geometric tolerance and manufacturability of parts manufactured by metal AM processes. Hence, future research should focus on studying tolerancing in other AM processes and apply novel design methodologies to a variety of processes and materials and research is needed to produce geometric tolerance and assemblability information that designers can refer to.

Much research in DfAM is concentrated in DfAM Specifics. These specifics include design methods and methodologies. For instance, Puttonen, (2019) developed a systematic requirements mapping, part and product-level functional analysis, a holistic functional analysis for product redesign and validated through an industrial case study. Dalpadulo et al., (2020) proposed a systematic redesign approach based on AM technologies that integrate topology optimisation and a tool for selecting design variants based on the optimisation of both product and process features. A decisionmaking methodology that can facilitate AM selection and assist in product/component design was developed by Liu, Zhu and Ye, (2020). 
The various tools developed in DfAM include tools for geometric modelling based design (Tedia and Williams, 2016), evolutionary algorithm-driven design (Huang et al., 2020; Gu et al., 2020) and theory-driven design, which are used for design representation, analysis and optimisation (Abdullah et al., 2020; Huang et al., 2020). Other aspects of the specifics that have been researched include DfAM guidelines on support structure removal (Gibson, Rosen and Stucker, 2014; Thompson et al., 2016), interlocking features (Baptista et al., 2020), and hollowing out parts for reduced printing time and materials (Yang and Zhao, 2015; Jiang, Xu and Stringer, 2019). To exploit the full potential of AM, research should focus on developing design theories, methods, tools, and techniques that will address constraints inherent in the association between geometry, materials, and quality to create powerful and value-added industrial solutions (Abdullah et al., 2020).

To exploit the potentials of AM, concept generation through ideation for both the design and redesign of components for AM is imperative. Ideation in DfAM has been studied as a method to enrich design methods to ensure user-tailored support, as guidelines to support concept generation, and using case studies in the automotive sector (Watschke et al., 2017; Richter et al., 2018; Boyd, 2019). Further work is needed to explore ideation from design tools and using the case study approach tailored toward various industries to understand how the difference in sectors, tools, and products influence the ideation of inexperienced designers. To date there has been comparatively little published on DfAM education, with the notable exception of works by Borgianni et al., (2019) and Prabhu et al., $(2019,2020)$ that attempted to assess the impact of DfAM knowledge on students' design ability. It is important that research should focus on not only transferring research on DfAM into appropropriate curricula but that it also accounts for different teaching styles and different design disciplines. This is needed to identify how to most successfully convey practical DfAM knowledge to design and engineering students at Higher Education level to enable them to gather the relevant skills needed in their future employment in industry.

Research in AM processes is mostly connected to other aspects of the classification as shown in the keyword analysis. The most researched AM processes as shown in figure xii are Selective Laser Sintering (SLS), Powder Bed Fusion (PBF), and Fused Deposition Modelling (FDM). For instance, Stolt and Elgh, (2020) investigated the impact of designing components with Selective Laser Melting. Other works focus on 
developing rules and guidelines for SLS (Finazzi et al., 2019), materials (Finazzi et al., 2020), functional capabilities (Boschetto et al., 2019). A new DfAM was illustrated by Medellin-Castillo and Zaragoza-Siqueiros, (2019) for FDM and Zhao and Guo, (2020) addressed non-planar slicing, path planning on curved surfaces, and multi-degree of freedom (DOF) on FDM. Research in PBF has addressed the optimisation of support materials and design (Ceccanti, Giorgetti and Citti, 2019), post-processing, product weight, and print time (Diegel et al., 2020), worksheet for identifying candidate parts for PBF (Bracken et al., 2020) and material properties of AM parts by PBF (Bracken et al., 2020). Future work should focus on replicating these studies using other AM processes. Such work should focus on finding the link between design strategies and methods, AM process parameters, and material development for each process.

\section{Conclusion}

The study investigated research in DfAM and analysed the results through a classification developed from the existing literature into DfAM potentials, DfAM limitations, DfAM specifics, and AM process and parameters. A bibliometric analysis was deployed to aid our understanding of recent and current research in DfAM using the SCOPUS database. Citation, co-authorship, and keyword analyses were performed and discussed using VoxViewer (a bibliometric analysis software). The main findings from the study are summarised below

- In recent years, the literature on DfAM has experienced accelerating growth with respect to the number of articles, citations, authors and institutions involved.

- The scientific literature dealing with studies on DfAM is geographically dispersed across a wide variety of outlets; 104 journals, 621 authors in 23 institutions from 33 countries, yet there is a significant concentration in 10 Journals that cover more than $35 \%$ of the identified sample.

- The three main journal outlets for DfAM research are "Procedia CIRP", "Proceedings of the International Conference on Engineering Design, ICED", and "Journal of Mechanical Design Transaction of ASME" while "Journal of Materials and Design" has the highest CPA.

- The high concentration of publications in conference proceedings is an indication that researchers in DfAM are keen on disseminating their findings rapidly through conferences, thereby promoting research in DfAM. However, researchers should attempt to cover conferences that are not only within their 
geographic domain (outside their location), to enable global dissemination of the developed DfAM knowledge.

- North America and Europe are the most fertile grounds regarding research in DfAM, with the USA and France ranking top in terms of productivity and research cooperation. At an institutional level, Pennsylvania State University (USA), Swiss Federal Institute of Technology Zurich (ETH Zurich) and Royal Melbourne Institute of Technology University (RMIT, Australia) stand out in terms of research output and frequent affiliations.

- Authors and institutions exhibit a sparse relationship in terms of crossinstitutional and international collaboration; knowledge development and international cooperation amongst scholars are limited. The existence of few key authors and a large number of single nodes without links in the coauthorship network implies a lack of a universal approach in the development of knowledge in DfAM and fragmentation in the field.

- Researchers appear to be mostly working in groups or teams within their institutions suggesting increasing specialisation within those instiutions which may be strategic. There may be obstacles to forming cross-institutional collaborations such as access to funding and or travel restrcitions or competitive strategies. Going forward, there clearly potential to develop international DfAM networks that bring researchers together to discuss ideas and develop research themes and collaborations that will potentially foster a global approach to DfAM knowledge development, accelerate development and lead to consensus and consistency.

- DfAM is a rapidly growing field. Over the past 5 years, it has developed substantial knowledge that is critical to the adoption of $A M$ as a mainstream production strategy. Despite this, the knowledge has not been fully disseminated as both researchers and designers still battle with exploiting the potentials of $A M$ as evident in the disparity between studies in the various DfAM classifications.

- More publications in DfAM must focus on developing underpinning knowledge that would be useful and form the foundation for other works to make an impact in this research field. Furthermore, the outputs should be impactful and attempt 
to offer solutions to industry-related problems and support knowledge transfer and learning.

- A significant contribution of this paper lies in the unraveling of the areas within the four classifications where future DfAM research should focus on. For the AM potential, research should focus on hierarchical and material complexities, customisation and personalisation, and other potential areas such as sustainability, cost implication and additional product values. In AM limitations, more effort is needed to study tolerancing and produce assemblability information as an input in the DfAM process. Regarding DfAM Specifics, future research should focus on conveying practical DfAM knowledge to students in Higher Education for increased employability in industry. Finally, future works should focus on identifying novel links between design strategies and methods, AM parameters and material development for each AM process.

Several important limitations of this study need to be considered. First, DfAM is not yet recognised as a "stand-alone" field of research, hence, the selection criteria and the adopted classification of documents were derived from convergence of terminaology and a subjective analysis. With this approach, accuracy is maximised but reproducibility is compromised. The transfer of data from Scopus to other platforms for analysis contributed to the reduced number of examined articles. Data capture and management in scientific repositories should be upgraded to avoid the loss of vital research information. Further, the predefined dates in Scopus present a limitation to the research outcome because it limits the amount of data obtained for analysis. However, to overcome this limitation, VOSviewer was used to capture additional data within the timeframe under investigation. The study was limited to publications in the English language and consequently, potentially significant works in other languages may have been missed. The quantitative nature of bibliometric analysis does not explain why authors refer to other works, which does not always reflect intellectual value but rather, visibility and access to publications, interpersonal relationships, institutional reputations, authors' reputation or citation impact (Caviggioli and Ughetto, 2019). 


\section{Reference}

Abdullah Alfaify, Mustafa Saleh, F. M. A. and and Abdulrahman M. Al-Ahmari (2020) 'Design for additive manufacturing - a systematic review', Sustainability, 10(19), pp. 3043-3054. doi: 10.1201/9780429466236-7.

Ameen, W. et al. (2018) 'Manufacturability of Overhanging Holes Using Electron Beam Melting', Metals, 8(6), p. 397. doi: 10.3390/met8060397.

Atzeni, E. and Salmi, A. (2012) 'Economics of additive manufacturing for end-usable metal parts', The International Journal of Advanced Manufacturing Technology, 62(9-12), pp. 1147-1155. doi: 10.1007/s00170-011-3878-1.

Aznarte Garcia, E., Qureshi, A. J. and Ayranci, C. (2018) 'A study on materialprocess interaction and optimization for VAT-photopolymerization processes', Rapid Prototyping Journal, 24(9), pp. 1479-1485. doi: 10.1108/RPJ-10-2017-0195.

Baldinger, M. et al. (2016) 'Additive manufacturing cost estimation for buy scenarios', Rapid Prototyping Journal, 22(6), pp. 871-877. doi: 10.1108/RPJ-02-2015-0023.

Baptista, R. J. S. et al. (2020) 'Joining aluminium profiles to composite sheets by additive manufacturing and forming', Journal of Materials Processing Technology. Elsevier, 279(January), p. 116587. doi: 10.1016/j.jmatprotec.2019.116587.

Battaïa, O. et al. (2018) 'Design for manufacturing and assembly/disassembly: joint design of products and production systems', International Journal of Production Research, 56(24), pp. 7181-7189. doi: 10.1080/00207543.2018.1549795.

Blösch-Paidosh, A. and Shea, K. (2018) 'Design Heuristics for Additive Manufacturing Validated Through a User Study 1', Journal of Mechanical Design, 141(4), p. 041101. doi: 10.1115/1.4041051.

Blösch-Paidosh, A. and Shea, K. (2019) 'Design Heuristics for Additive Manufacturing Validated Through a User Study ${ }^{1}$, Journal of Mechanical Design, 141(4), p. 041101. doi: 10.1115/1.4041051.

Borgianni, Y. et al. (2019) 'University education in additive manufacturing and the need to boost design aspects', Proceedings of the International Conference on Engineering Design, ICED, 2019-Augus(AUGUST), pp. 629-638. doi: 10.1017/dsi.2019.67.

Boschetto, A. et al. (2019) 'Selective Laser Melting of a 1U CubeSat structure. Design for Additive Manufacturing and assembly', Acta Astronautica. Elsevier Ltd, 159(January), pp. 377-384. doi: 10.1016/j.actaastro.2019.03.041.

Boyd, I. . M. F. (2019) 'Design for Additive Manufacturing: effectiveness of Unit Cell Design Guidelines as Ideation Tools', pp. 1-11.

Bracken, J. et al. (2020) 'Design for metal powder bed fusion: The geometry for additive part selection (GAPS) worksheet', Additive Manufacturing. Elsevier, 35(March), p. 101163. doi: 10.1016/j.addma.2020.101163.

Cao, P. et al. (2018) 'Design for Additive Manufacturing: Optimization of Piping Network in Compact System With Enhanced Path-Finding Approach', Journal of 
Manufacturing Science and Engineering, 140(8), p. 081013. doi: 10.1115/1.4040320.

Castelão, A. et al. (2019) 'Design for AM: Contributions from surface finish, part geometry and part positioning', Procedia CIRP. Elsevier B.V., 84, pp. 491-495. doi: 10.1016/j.procir.2019.04.247.

Caviggioli, F. and Ughetto, E. (2019) 'A bibliometric analysis of the research dealing with the impact of additive manufacturing on industry, business and society', International Journal of Production Economics. Elsevier B.V., 208(November 2018), pp. 254-268. doi: 10.1016/j.ijpe.2018.11.022.

Ceccanti, F., Giorgetti, A. and Citti, P. (2019) 'A support structure design strategy for laser powder bed fused parts', Procedia Structural Integrity. Elsevier B.V., 24(2019), pp. 667-679. doi: 10.1016/j.prostr.2020.02.059.

Chekurov, S. and Lantela, T. (2017) 'Selective Laser Melted Digital Hydraulic Valve System', 3D Printing and Additive Manufacturing, 4(4), pp. 215-221. doi: 10.1089/3dp.2017.0014.

Chiu, MC and YH, Lin (2016) 'Simulation based method considering design for additive manufacturing and supply chain: An empirical study of lamp industry', Industrial Management \& Data Systems. Available at:

https://www.emeraldinsight.com/doi/abs/10.1108/IMDS-07-2015-0266 (Accessed: 5 March 2019).

Christopher, Williams; Logan, S. A. W. (2015) 'Advancing Student learning of Design for Additive Manufacturing Principles trough an extracurricular Vehicle Design Competition', in Proceedings of the ASME 2015 International Design Engineering Technical Conferences \& Computers and Information in Engineering Conference. Boston, Massachusetts, USA: ASME, pp. 1-8.

Chu, C., Graf, G. and Rosen, D. W. (2008) 'Design for additive manufacturing of cellular structures', Computer-Aided Design and Applications, 5(5), pp. 686-696. doi: 10.3722/cadaps.2008.686-696.

Clausen, A., Aage, N. and Sigmund, O. (2015) 'Topology optimization of coated structures and material interface problems', Computer Methods in Applied Mechanics and Engineering, 290, pp. 524-541. doi: 10.1016/j.cma.2015.02.011.

Dalpadulo, E. et al. (2020) 'Integration of topology optimisation and design variants selection for additive manufacturing-based systematic product redesign', Applied Sciences (Switzerland), 10(21), pp. 1-13. doi: 10.3390/app10217841.

Diegel, O. et al. (2020) 'Design for additive manufacturing process for a lightweight hydraulic manifold', Additive Manufacturing. Elsevier, 36(June), p. 101446. doi: 10.1016/j.addma.2020.101446.

Ellena, T. et al. (2018) 'A design framework for the mass customisation of custom-fit bicycle helmet models', International Journal of Industrial Ergonomics, 64, pp. 122133. doi: 10.1016/j.ergon.2018.01.005.

Fessl, J. et al. (2018) 'Liquid rocket engine design for additive manufacturing', Proceedings of the International Astronautical Congress, IAC, 2018-Octob(May), p. 
2021.

Finazzi, V. et al. (2019) 'Design rules for producing cardiovascular stents by selective laser melting: Geometrical constraints and opportunities', Procedia Structural Integrity. Elsevier B.V., 15, pp. 16-23. doi: 10.1016/j.prostr.2019.07.004.

Finazzi, V. et al. (2020) 'Design and functional testing of a novel balloon-expandable cardiovascular stent in $\mathrm{CoCr}$ alloy produced by selective laser melting', Journal of Manufacturing Processes. Elsevier, 55(April), pp. 161-173. doi:

10.1016/j.jmapro.2020.03.060.

François, M. et al. (2019) 'Design for additive manufacturing (DfAM) methodologies: a proposal to foster the design of microwave waveguide components', Virtual and Physical Prototyping, 14(2), pp. 175-187. doi: 10.1080/17452759.2018.1549901.

Gao, W. et al. (2015) 'The status, challenges, and future of additive manufacturing in engineering', CAD Computer Aided Design. Elsevier Ltd, 69, pp. 65-89. doi: 10.1016/j.cad.2015.04.001.

Gebisa, A. W. and Lemu, H. G. (2017) 'Design for manufacturing to design for Additive Manufacturing: Analysis of implications for design optimality and product sustainability', Procedia Manufacturing. Elsevier B.V., 13, pp. 724-731. doi: 10.1016/j.promfg.2017.09.120.

Gibson, I., Rosen, D. and Stucker, B. (2014) 'Additive Manufacturing Technologies: 3D Printing and Direct Digital Manufacturing, Springer, New York', (3), p. 498.

Graziosi, S. et al. (2020) 'Design and testing of an innovative 3D-printed metalcomposite junction', Additive Manufacturing. Elsevier, 36(May), p. 101311. doi: 10.1016/j.addma.2020.101311.

Greer, C. et al. (2019) 'Introduction to the Design Rules for Metal Big Area Additive Manufacturing', Additive Manufacturing. doi: 10.1016/j.addma.2019.02.016.

Gu, G. et al. (no date) 'Algorithm-driven design of fracture resistant composite materials realized through additive manufacturing', Elsevier. Available at: https://www.sciencedirect.com/science/article/pii/S2214860417300052 (Accessed: 22 February 2019).

Guariento, L. et al. (2020) 'Graded Gyroid Structures for Load Bearing Orthopedic Implants', Proceedings of the 2020 IEEE 10th International Conference on 'Nanomaterials: Applications and Properties', NAP 2020, pp. 9-13. doi: 10.1109/NAP51477.2020.9309692.

Hallmann, M., Schleich, B. and Wartzack, S. (2019) 'A method for analyzing the influence of process and design parameters on the build time of additively manufactured components', Proceedings of the International Conference on Engineering Design, ICED, 2019-August, pp. 649-658. doi: 10.1017/dsi.2019.69.

Hanks, B. et al. (2020) 'Mechanical properties of additively manufactured metal lattice structures: Data review and design interface', Additive Manufacturing. Elsevier, 35(May), p. 101301. doi: 10.1016/j.addma.2020.101301.

Hegab, H. A. (2016) ‘Design for additive manufacturing of composite materials and 
potential alloys: a review', Manufacturing Review, 3, p. 11. doi: 10.1051/mfreview/2016010.

Huang, J. et al. (2020) 'A survey of design methods for material extrusion polymer 3D printing', Virtual and Physical Prototyping. Taylor \& Francis, 15(2), pp. 148-162. doi: 10.1080/17452759.2019.1708027.

Jansen, B., Doubrovski, E. L. and Verlinden, J. C. (2014) 'Animaris geneticus parvus: Design of a complex multi-body walking mechanism', Rapid Prototyping Journal, 20(4), pp. 311-319. doi: 10.1108/RPJ-10-2012-0087.

Järvinen, J. P. et al. (2014) 'Characterization of effect of support structures in laser additive manufacturing of stainless steel', Physics Procedia. Elsevier B.V., 56(C), pp. 72-81. doi: 10.1016/j.phpro.2014.08.099.

Jiang, J., Xu, X. and Stringer, J. (2019) 'Optimization of process planning for reducing material waste in extrusion based additive manufacturing', Robotics and Computer-Integrated Manufacturing. Elsevier Ltd, 59(April), pp. 317-325. doi: 10.1016/j.rcim.2019.05.007.

Ko, H., Moon, S. K. and Otto, K. (2014) 'Customization Design Knowledge Representation to Support Additive Manufacturing', in Proceedings of the 1st International Conference on Progress in Additive Manufacturing. Singapore: Research Publishing Services, pp. 13-18. doi: 10.3850/978-981-09-0446-3_098.

Kretzschmar, N. and Chekurov, S. (2018) 'The Applicability of the 40 TRIZ Principles in Design for Additive Manufacturing', in, pp. 0888-0893. doi: 10.2507/29th.daaam.proceedings.128.

Kumke, M. et al. (2018) 'Methods and tools for identifying and leveraging additive manufacturing design potentials', International Journal on Interactive Design and Manufacturing, 12(2), pp. 481-493. doi: 10.1007/s12008-017-0399-7.

Kumke, M., Watschke, H. and Vietor, T. (2016) 'A new methodological framework for design for additive manufacturing', Virtual and Physical Prototyping, 11(1), pp. 3-19. doi: 10.1080/17452759.2016.1139377.

Kuschmitz, S. et al. (2021) 'Design and Additive Manufacturing of Porous Sound Absorbers-A Machine-Learning Approach', Materials, 14(7), p. 1747. doi: 10.3390/ma14071747.

Laverne, F. et al. (2015) 'Assembly Based Methods to Support Product Innovation in Design for Additive Manufacturing: An Exploratory Case Study', Journal of Mechanical Design, 137(12), p. 121701. doi: 10.1115/1.4031589.

Laverne, F. et al. (2017) 'A framework for manufacturing execution system deployment in an advanced additive manufacturing process', International Journal of Product Lifecycle Management, 10(1), p. 1. doi: 10.1504/ijplm.2017.10003809.

Lettori, J. et al. (2020) 'Additive manufacturing adoption in product design: An overview from literature and industry', Procedia Manufacturing. Elsevier B.V., 51(2019), pp. 655-662. doi: 10.1016/j.promfg.2020.10.092.

Leutenecker-Twelsiek, B., Klahn, C. and Meboldt, M. (2016) 'Considering Part 
Orientation in Design for Additive Manufacturing', Procedia CIRP. Elsevier B.V., 50, pp. 408-413. doi: 10.1016/j.procir.2016.05.016.

Li, S. et al. (2021) 'Design for additive manufacturing from a force-flow perspective', Materials and Design. Elsevier Ltd, 204, p. 109664. doi:

10.1016/j.matdes.2021.109664.

Lim, Y.-E., Park, J.-H. and Park, K. (2018) 'Automatic Design of 3D Conformal Lightweight Structures Based on a Tetrahedral Mesh', International Journal of Precision Engineering and Manufacturing-Green Technology, 5(4), pp. 499-506. doi: 10.1007/s40684-018-0053-2.

Lim, Y. et al. (2017) 'Design for additive manufacturing of customized cast with porous shell structures', Springer, 31(11), pp. 5477-5483. Available at: https://link.springer.com/article/10.1007/s12206-017-1042-z (Accessed: 5 March 2019).

Liu, J. (2016) 'Guidelines for AM part consolidation', Virtual and Physical Prototyping, 11(2), pp. 133-141. doi: 10.1080/17452759.2016.1175154.

Liu, S. et al. (2015) 'An identification method for enclosed voids restriction in manufacturability design for additive manufacturing structures', Frontiers of Mechanical Engineering, 10(2), pp. 126-137. doi: 10.1007/s11465-015-0340-3.

Liu, W., Zhu, Z. and Ye, S. (2020) 'A decision-making methodology integrated in product design for additive manufacturing process selection', Rapid Prototyping Journal, (October). doi: 10.1108/RPJ-06-2019-0174.

Mani, M., Witherell, P. and Jee, H. (2017) 'Design Rules for Additive Manufacturing: A Categorization', in Volume 1: 37th Computers and Information in Engineering Conference. ASME, p. V001T02A035. doi: 10.1115/detc2017-68446.

Martusevich, K. and Sen, C. (2017) 'An Empirical Design Tool for Estimating InPlane Diametric Shrinkage and Bulging of Circular Cylinders Made With FusedDeposition Modeling', in Volume 4: 22nd Design for Manufacturing and the Life Cycle Conference; 11th International Conference on Micro- and Nanosystems. ASME, p. V004T05A011. doi: 10.1115/DETC2017-68039.

Medellin-Castillo, H. I. and Zaragoza-Siqueiros, J. (2019) 'Design and Manufacturing Strategies for Fused Deposition Modelling in Additive Manufacturing: A Review', Chinese Journal of Mechanical Engineering (English Edition). Springer Singapore, 32(1). doi: 10.1186/s10033-019-0368-0.

Nguyen, C. H. P. and Choi, Y. (2020) 'Concurrent density distribution and build orientation optimization of additively manufactured functionally graded lattice structures', CAD Computer Aided Design. Elsevier Ltd, 127, p. 102884. doi: 10.1016/j.cad.2020.102884.

Oh, Y., Zhou, C. and Behdad, S. (2018) 'Part decomposition and assembly-based $(\mathrm{Re})$ design for additive manufacturing: A review', Additive Manufacturing, pp. 230242. doi: 10.1016/j.addma.2018.04.018.

Opgenoord, M. M. J. and Willcox, K. E. (2019) 'Design for additive manufacturing: 
cellular structures in early-stage aerospace design', Structural and Multidisciplinary Optimization. Structural and Multidisciplinary Optimization, 60(2), pp. 411-428. doi: 10.1007/s00158-019-02305-8.

Orquéra, M., Campocasso, S. and Millet, D. (2017) 'Design for Additive Manufacturing Method for a Mechanical System Downsizing', in Procedia CIRP, pp. 223-228. doi: 10.1016/j.procir.2017.02.011.

Piechowski, L. D. and Rehman, U. (2011) 'Design process decionstructed: the industry case of an elevator button assembly redesigned for Additive Manufacturing', Handbook of Forensic Assessment: Psychological and Psychiatric Perspectives, pp. 459-478. doi: 10.1002/9781118093399.ch20.

Polini, W. et al. (2017) 'CIRP Annals - Manufacturing Technology Geometrical product specification and verification in additive manufacturing', CIRP Annals Manufacturing Technology, 66, pp. 157-160. doi: 10.1016/j.cirp.2017.04.043.

Ponche, R. et al. (2014) 'A novel methodology of design for Additive Manufacturing applied to Additive Laser Manufacturing process', Robotics and Computer-Integrated Manufacturing, 30(4), pp. 389-398. doi: 10.1016/j.rcim.2013.12.001.

Prabhu, R. et al. (2019) 'But will it print?: Assessing student use of design for additive manufacturing and exploring its effect on design performance and manufacturability', Proceedings of the ASME Design Engineering Technical Conference, 2A-2019, pp. 1-13. doi: 10.1115/DETC2019-97478.

Prabhu, R. et al. (2020) 'Exploring the Effects of Additive Manufacturing Education on Students' Engineering Design Process and its Outcomes', Journal of Mechanical Design, Transactions of the ASME, 142(4), pp. 1-11. doi: 10.1115/1.4044324.

Pradel, P. et al. (2018a) 'A framework for mapping design for additive manufacturing knowledge for industrial and product design', Journal of Engineering Design, 29(6), pp. 291-326. doi: 10.1080/09544828.2018.1483011.

Pradel, P. et al. (2018b) 'Investigation of design for additive manufacturing in professional design practice', Journal of Engineering Design, 29(4-5), pp. 165-200. doi: 10.1080/09544828.2018.1454589.

Qi, Q. et al. (2018) 'A categorical framework for formalising knowledge in additive manufacturing', Procedia CIRP. Elsevier B.V., 75, pp. 87-91. doi:

10.1016/j.procir.2018.04.076.

Ramírez, E. A. et al. (2019) 'Methodology for design process of a snap-fit joint made by additive manufacturing', Procedia CIRP. Elsevier B.V., 79, pp. 113-118. doi: 10.1016/j.procir.2019.02.021.

Ranjan, R., Samant, R. and Anand, S. (2015) 'Design for Manufacturability in Additive Manufacturing Using a Graph Based Approach', p. V001T02A069. doi: 10.1115/msec2015-9448.

Ranjan, R., Samant, R. and Anand, S. (2016) 'Integration of Design for Manufacturing Methods With Topology Optimization in Additive Manufacturing', Journal of Manufacturing Science and Engineering, 139(6), p. 061007. doi: 
Richter, T. et al. (2018) 'Exploitation of potentials of additive manufacturing in ideation workshops', Proceedings of the International Conference on Engineering Design, ICED, (May), pp. 1-8.

Rosen, D. W. (2007) 'Computer-Aided Design for Additive Manufacturing of Cellular Structures', Computer-Aided Design and Applications, 4(5), pp. 585-594. doi: 10.1080/16864360.2007.10738493.

Rosen, D. W. (2014) 'Research supporting principles for design for additive manufacturing: This paper provides a comprehensive review on current design principles and strategies for AM', Virtual and Physical Prototyping. Taylor \& Francis, 9(4), pp. 225-232. doi: 10.1080/17452759.2014.951530.

Rupal, B. S. et al. (2020) 'Geometric tolerance and manufacturing assemblability estimation of metal additive manufacturing (AM) processes', Materials and Design. The Authors, 194, p. 108842. doi: 10.1016/j.matdes.2020.108842.

Salonitis, K. (2016) 'Design for additive manufacturing based on the axiomatic design method', International Journal of Advanced Manufacturing Technology, 87(14), pp. 989-996. doi: 10.1007/s00170-016-8540-5.

Seepersad, C.C., Govett, T., Kim, K., Lundin, M., Pinero, D. (2021) 'A designer's guide for dimensioning and tolerancing SLS parts', (May), p. 2021.

Shabat, Y. Ben and Fischer, A. (2015) 'Design of porous micro-structures using curvature analysis for additive-manufacturing', in Procedia CIRP, pp. 279-284. doi: 10.1016/j.procir.2015.01.057.

Sossou, G. et al. (2018) 'An additive manufacturing oriented design approach to mechanical assemblies', Journal of Computational Design and Engineering. Society for Computational Design and Engineering, 5(1), pp. 3-18. doi:

10.1016/j.jcde.2017.11.005.

Spallek, J. and Krause, D. (2016a) 'Process Types of Customisation and Personalisation in Design for Additive Manufacturing Applied to Vascular Models', Procedia CIRP, 50, pp. 281-286. doi: 10.1016/j.procir.2016.05.022.

Spallek, J. and Krause, D. (2016b) 'Process Types of Customisation and Personalisation in Design for Additive Manufacturing Applied to Vascular Models', Procedia CIRP, 50, pp. 281-286. doi: 10.1016/j.procir.2016.05.022.

Stolt, R. and Elgh, F. (2020) 'Introducing design for selective laser melting in aerospace industry', Journal of Computational Design and Engineering. Oxford University Press, 7(4), pp. 489-497. doi: 10.1093/jcde/qwaa042.

Taddese, G., Durieux, S. and Duc, E. (2020) 'Sustainability performance indicators for additive manufacturing: a literature review based on product life cycle studies', International Journal of Advanced Manufacturing Technology. The International Journal of Advanced Manufacturing Technology, 107(7-8), pp. 3109-3134. doi: 10.1007/s00170-020-05249-2.

Tamburrino, F., Graziosi, S. and Bordegoni, M. (2018) 'The Design Process of 
Additively Manufactured Mesoscale Lattice Structures: A Review', Journal of Computing and Information Science in Engineering, 18(4), p. 040801. doi: 10.1115/1.4040131.

Tammas-Williams, S. and Todd, I. (2017) 'Design for additive manufacturing with site-specific properties in metals and alloys', Scripta Materialia, 135, pp. 105-110. doi: 10.1016/j.scriptamat.2016.10.030.

Tang, Y., Hascoet, J.-Y. and Zhao, Y. F. (2014) 'Integration of Topological and Functional Optimization in Design for Additive Manufacturing', in Volume 1: Applied Mechanics; Automotive Systems; Biomedical Biotechnology Engineering; Computational Mechanics; Design; Digital Manufacturing; Education; Marine and Aerospace Applications. ASME, p. V001T06A006. doi: 10.1115/esda2014-20381.

Tavcar, J. and Nordin, A. (2021) 'Multi-Criteria Assessment and Process Selection Model for Additive Manufacturing in the Conceptual Phase of Design', Proceedings of the Design Society, 1(AUGUST), pp. 2197-2206. doi: 10.1017/pds.2021.481.

Tedia, S. and Williams, C. B. (2016) 'Manufacturability analysis tool for additive manufacturing using voxel-based geometric modeling', Solid Freeform Fabrication 2016: Proceedings of the 27th Annual International Solid Freeform Fabrication Symposium - An Additive Manufacturing Conference, SFF 2016, pp. 3-22.

Thompson, M. K. et al. (2016) 'Design for Additive Manufacturing: Trends, opportunities, considerations, and constraints', CIRP Annals - Manufacturing Technology, 65(2), pp. 737-760. doi: 10.1016/j.cirp.2016.05.004.

Tronvoll, S. A., Elverum, C. W. and Welo, T. (2018) 'Dimensional accuracy of threads manufactured by fused deposition modeling', in Procedia Manufacturing, pp. 763-773. doi: 10.1016/j.promfg.2018.07.088.

Ullah, R., Akmal, J. S., Laakso, S., et al. (2020) 'Anisotropy of additively manufactured 18Ni-300 maraging steel: Threads and surface characteristics', Procedia CIRP. Elsevier B.V., 93, pp. 68-78. doi: 10.1016/j.procir.2020.04.059.

Ullah, R., Akmal, J. S., Laakso, S. V. A., et al. (2020) 'Anisotropy of additively manufactured AISi10Mg: threads and surface integrity', International Journal of Advanced Manufacturing Technology, 107(9-10), pp. 3645-3662. doi: 10.1007/s00170-020-05243-8.

Vayre, B., Vignat, F. and Villeneuve, F. (2013) 'Identification on Some Design Key Parameters for Additive Manufacturing: Application on Electron Beam Melting', Procedia CIRP, 7, pp. 264-269. doi: 10.1016/j.procir.2013.05.045.

Vega-Moreno, A. et al. (2020) 'Design for additive manufacture (DfAM): the "equivalent continuum material" for cellular structures analysis', 1145028(December 2020), p. 84. doi: 10.1117/12.2560999.

Watschke, H. et al. (2017) 'A methodical approach to support ideation for additive manufacturing in design education', 21st International Conference on Engineering Design, 5(May), pp. 41-50.

Watschke, H. et al. (2021) 'Novel resistive sensor design utilizing the geometric 
freedom of additive manufacturing', Applied Sciences (Switzerland), 11(1), pp. 1-15. doi: 10.3390/app11010113.

Wulle, F. et al. (2017) 'Workpiece and Machine Design in Additive Manufacturing for Multi-Axis Fused Deposition Modeling', Procedia CIRP, 60, pp. 229-234. doi: 10.1016/j.procir.2017.01.046.

Yang, S. and Zhao, Y. F. (2015) 'Additive manufacturing-enabled design theory and methodology: a critical review', International Journal of Advanced Manufacturing Technology, pp. 327-342. doi: 10.1007/s00170-015-6994-5.

Zeng, K. (2015) 'Optimization of support structures for selective laser melting.' doi: $10.18297 /$ etd/2221.

Zhao, D. and Guo, W. (2020) 'Shape and Performance Controlled Advanced Design for Additive Manufacturing: A Review of Slicing and Path Planning', Journal of Manufacturing Science and Engineering, Transactions of the ASME, 142(1), pp. 123. doi: $10.1115 / 1.4045055$.

Zhu, Z. et al. (2018) 'Machine learning in tolerancing for additive manufacturing', CIRP Annals, 67(1), pp. 157-160. doi: 10.1016/j.cirp.2018.04.119.

Zwier, M. P. and Wits, W. W. (2016) 'Design for Additive Manufacturing: Automated Build Orientation Selection and Optimization', in Procedia CIRP, pp. 128-133. doi: 10.1016/j.procir.2016.08.040. 